«Душа человеческая разрушается от войны...»: письменные источники периода Первой мировой войны как ресурс гендерно ориентированной истории эмоций

\author{
О.В. Чуракова
}

Высшая школа социально-гуманитарных наук и международных коммуникаций Северного (Арктического) федерального университета имени М.В. Ломоносова; 163002, Россия, Архангельск, Набережная Северной Двины, д. 17; koi202@mail.ru

\title{
"Human soul is destroyed by war...": written sources of World War I period as a resource for gender-oriented history of emotions
}

\author{
Olga V. Churakova \\ Higher School of Social Sciences, Humanities and International Communication, \\ Northern (Arctic) Federal University named after M.V. Lomonosov; \\ 17, Nabereznay Severnoy Dviny, Arkhangelsk, 163002, Russia; koi202@mail.ru
}

Аннотация: В статье анализируются проблемы и перспективы использования письменных источников периода Первой мировой войны для проведения гендерной экспертизы российского прошлого в русле истории эмоций как актуального направления культурно-исторической антропологии. Понятия «эмоции» и «чувства» в данном случае рассматриваются как синонимы. Комплекс письменных «гендерно-окрашенных» источников за 1914-1918 гг. достаточно велик и разнообразен и включает в себя архивные материалы, коллекции документов историко-партийных комиссий, мемуары, письма, дневники, женскую прессу, анкеты («самопереписи») слушательниц высших женских курсов. Однако данный корпус свидетельств прошлого неравноценен по степени трансляции чувств и отражению эмоционального фона эпохи. Автором проведено ранжирование эмоциональных сообществ по социальной принадлежности и «слышимости» голосов в истории - репрезентативности источников. К первой категории эмоциональных сообществ относятся представительницы правящего до марта 1917 г. Дома Романовых и аристократки. Их документы личного происхождения опубликованы в достаточной мере, обширные фонды документов находятся в центральных российских и зарубежных архивах. Часть женщин элиты входила в другое эмоциональное сообщество - «фронтовички». Третьей категорией эмоциональных сообществ являются городские жительницы. Их «разноголосица» представлена частично меморатом, а также отражена в материалах женских журналов, студенческих анкетах, документах региональных архивов. Наименее представлены с точки зрения эмоций самые многочисленные сообщества - крестьянки и солдатки, несмотря на то, что повседневная жизнь и ценностные ориентации последних хорошо исследованы. Для выявления психологический матрицы эпохи важно использовать весь комплекс выявленных источников.

Ключевые слова: история эмоций, история чувств, письменные источники, Первая мировая война, гендерные исследования, эмоциональное сообщество

Для цитирования: Чуракова О.В. «Душа человеческая разрушается от войны...»: Письменные источники периода Первой мировой войны как ресурс гендерно-ориентированной истории эмоций // Вестник Российского университета дружбы народов. Серия: История России. 2019. Т. 18. № 2. С. 246-277. https://doi.org/10.22363/2312-8674-2019-18-2-246-277 
Abstract: The article analyzes the problems and prospects of using written sources of World War I period for a gender studies approach to Russia's past, in line with the history of emotions in cultural-historical anthropology. The terms "emotions" and "feelings" are viewed as synonyms. The article states that what the historian encounters in the sources is mostly an emotional state or mood (personal or collective) as well as experiences, passions or sensations, rather than "pure" emotions and feelings. The corpus of "gender-marked" written sources of the 1914-1918 period is huge and varied, and includes materials from archives, collections of party commissions, published memoirs, letters, diaries, the women's press, as well as profile documents ("self-census") of female students. However, these sources unevenly reflect the feelings and the emotional background of the era. Following the conceptual framework developed by Barbara Rosenwein, we can speak of several emotional communities defined by the social affiliation and the "audibility" of the particular voices in history, i.e. the representativeness of the sources. The first category of emotional communities comprises the women of the Romanov family and noblewomen more broadly. Russian and foreign archives boast extensive collections of their personal documents. The second category includes "frontovichky" - frontline women-soldiers. Urban women belong to a third category, and are represented by memory-based stories, the women's press, female students' profiles, and documents from regional archives. From the point of view of emotions, the biggest yet least represented community were peasant women. While their everyday life and values have been well researched, only very few notes and diaries from their hands have survived. Letters to the front were partially preserved (esp. those intercepted by the authorities) and are now stored in the State Archive of the Russian Federation). For the identification of the psychological matrix of the era it is crucial to use the full set of these sources.

Keywords: history of emotions, history of feelings, written sources, World War I, gender studies, emotional community

For citation: Churakova, Olga V. “ 'The human soul is destroyed by war ...' Written sources of World War I as a resource for a gender-oriented history of emotions," RUND Journal of Russian History 18, no. 2 (May 2019): 246-277. https://doi.org/10.22363/2312-8674-2019-18-2-246-277

\section{Введение}

Антропологический ренессанс научного знания в конце XX в. вызвал к жизни немало новых направлений творческого поиска ученых. Одним из них явилась история эмоций или историческая эмоционология. В начале нынешнего столетия изучение истории эмоций и чувств человека неправомерно было бы назвать «невозделанным полем» научных изысканий. Появившись на Западе в 80-е гг. XX в., данные исследования достаточно быстро завоевали симпатии представителей наук о человеке (социологов, этнологов, философов, историков, лингвистов).

Психологи опередили социологов в изучении феномена эмоций на сто лет. В 1884 г. появилась статья американского психолога и философа Уильяма Джеймса «Что такое эмоция?», и практически в это же время датский физиолог и анатом Карл Георг Ланге исследовал понятия «радость», «страх», «грусть», «гнев», причем не только физиологические реакции эмоций, но и поведенческие их проявления. В XX - начале XXI в. традицию изучения эмоций продолжили целый ряд ученых: американский антрополог из Дьюкского университета Уильям М. Редди («Навигация эмоций), профессор Калифорнийского университета Даниэль Гросс («Секретная история эмоций»), психолог из Сан-Франциско Пол Экман («Психология эмоций») и другие.

Что касается изучения научной траектории «истории эмоций», то ее начали осваивать параллельно социологи и историки, поэтому исследователи расходятся 
во мнении о том, кого следует считать «крестным отцом» данного дискурса. Признанный специалист в области истории эмоций социолог О.А. Симонова полагает, что «Феей-крестной» явилась социолог Арли Хохшильд (A. Hochschild), которая занималась темой эмоциональной культуры еще в 1970-е гг. Однако в 1985 г. в США вышла книга Питера и Кэрол Стренсов «Эмоционология: проясняя историю эмоций и эмоциональные стандарты», в которой ученые объявили о создании новой дисциплины, способной измерять градусы «эмоциональной температуры» «коллективного прошлого» ${ }^{1}$. Таким образом, и их можно считать родоначальниками «эмоционологии» как самостоятельной научной дисциплины.

Между тем применительно к изучению прошлого методологические основания исследования истории чувств и эмоций были заложены в работах Йохана Хёйзинга и Люсьена Февра, обратившихся к теме «чувствительности в истории» еще в первой половине XX в. Новая волна интереса к истории эмоций пришлась на последнее десятилетие XX в. Как полагают исследователи, на грани столетий миллениума в гуманитарном знании в странах Европы, Америке, Канаде произошел «эмоциональный поворот» или даже «переворот». В 1990 г. в Иерусалиме прошла конференция «Historicity of Emotions». В это же время американский профессор истории Барбара Розенвейн (B. Rosenwein) разработала концепцию «эмоционального сообщества» (emotional community), а антрополог из США Уильям Редди (W. Reddy) ввел понятие «эмотив» (emotive).

Но настоящая «золотая лихорадка» охватила ученых-эмоционологов после террористического акта в Нью-Йорке 9 сентября 2001 г. «Ответом» на вызов «9/11» стало усиленное исследование дефиниций «страх», «ужас». В Европе даже начал издаваться журнал «Страх». Особенно много на тему негативных эмоции в начале XXI в. появилось философской и культурологической рефлексии. Например, норвежский историк и философ из Университета Бергена Ларс Свендсен (Lars Fr. H. Svendsen) проанализировал категории «страха» и «ужаса», опираясь на наследие гуманитарного знания в этой области ${ }^{2}$. Еще один профессор философии из Норвегии - Аре Юхан Ветлес (A. Vetlesen) изучил эмоции, связанные с физической и психической природой «боли» ${ }^{3}$. Следует отметить, российские ученые также предпринимали попытку исследовать «все страхи мира» в прошлом и настоящем: В Санкт-Петербурге в Пушкинском доме в 2014 г. на эту тему состоялась научная конференция. Результатом научного форума стала публикация сборника статей, где авторы, анализируя генезис и специфику образного воплощения «страха», попытались «приблизиться к пониманию механизмов, которых зиждется смысл и власть «ужаса», апеллируя к разным историческим эпохам 4 .

Следует отметить, что работы, связанные с проявлением эмоций и чувств, создавались философами в Советской России, однако многие из них увидели свет

${ }^{1}$ Винниикий И. Заговор чувств или русская история на «эмоциональном повороте» (Обзор работ по истории эмоций) // Новое литературное обозрение. 2012. № 117. С. 441-460.

2 Свендсен Л. Философия страха. М.: Прогресс-Традиция, 2010.

3 Ветлесен А.Ю. Философия боли. М.: Прогресс-Традиция, 2010.

${ }^{4}$ Все страхи мира: Horror в литературе и искусстве. Сб. статей. СПб.; Тверь: Изд-во Марины Батасовой, 2015. 
лишь в годы перестройки. Например, таковой является судьба монографии В.К. Бакшутова «Философия чувств: информационная концепция».

Автор прослеживает процесс становления социальных чувств в истории человечества, выделяя такие периоды, как «социальные чувства древних цивилизаций», «средневековую сентиментальность», «социальные чувства техногенной цивилизации» и др. В поле зрения ученого оказались такие проявления эмоций и чувств, как «страх», «сострадание», «фанатизм», «эгоизм» и другие.

Автор труда затрагивает и этические темы, например, «вырождение любви» в техногенных цивилизациях ${ }^{5}$. В подобном же ключе морально-нравственных конвенций рассматривает норвежский философ Хельге Сваре (Helge Svare) демонстрации чувств и эмоций, которые связаны с понятием «дружба» (восхищение, уважение) и категориями «любовь», «счастье». Кроме того, автор на основе источников проводит «экскурсию» в историю эмоций, предлагая читателю побывать с ним «в саду Эпикура» или «за средневековыми монастырскими стенами». Гендерные аспекты исследования представлены в книге главой «Женская дружба в XVII и XVIII веках» ${ }^{6}$.

Не могли обойти вниманием данное направление и литературоведы. Филологами выпущен учебник с методикой анализа эмоций в тексте. Лингвисты называют данное направление «эмоциологией» ${ }^{7}$.

Таким образом, исследование проявлений эмоций и чувств в контексте развития человечества в современном гуманитарном знании представляет собой разнообразный и разноуровневый интеллектуальный ландшафт.

Ученые даже предлагают назвать культуру XXI в. новым «чувствительным веком» или новым «сентиментальным веком» ${ }^{8}$. Особенно это актуально для российской и европейской культур, где уже была, по выражению академика А.Н. Веселовского, «эпоха чувствительности», пришедшая на смену «рассудочной» культуре века Просвещения9.

Исследуя причины появления «взрыва» интереса к эмоциям в науке и повседневной жизни, социолог Ольга Симонова приходит к выводу, что сочетание «рационального отношения к эмоциям и одновременно особое внимание к чувствам, взрывы коллективных эмоций ... характеризуют эмоциональную культуру современности» ${ }^{10}$.

${ }^{5}$ Бакшутов В.К. Философия чувств: информационная концепция. Екатеринбург: УрО РАН, 1996. C. 379-394.

${ }^{6}$ Сваре X. Философия дружбы. М.: Прогресс-Традиция, 2010.

7 Филимонова O.E. Эмоциология текста. Анализ репрезентации эмоций в английском тексте: Учебное пособие. СПб.: Книжный Дом, 2007. С. 7.

${ }^{8}$ Симонова О. Изучение эмоций как область междисциплинарной интеграции: история и социология в поисках объяснения «эмоционального поворота». К выходу русского перевода криги Яна Плампера «История эмоций» // Социологическое обозрение. 2018. Т. 17. №. 3. С. 356-378.

9 Веселовский А.Н. Эпоха чувствительности // Избранные статьи. Л.: Гослитиздат, 1939. С. 487.

${ }^{10}$ O. Simonova, "Capitalist Heart: Rationality, Emotion and Alienation in Late Modern Societies," in Power, Violence and Justice: reflections, responses and responsibilities. Book of Abstracts accepted for presentation at the XIX ISA World Congress of Sociology Toronto, Canada, July 15-21, 2018 (Toronto: International Sociological Association), 891. 
Социологи констатируют институционализацию социологии эмоций как субдисциплины, однако, все еще сомневаются, «стала ли социология эмоций «принцессой» (как Золушка) современной социологии?» ${ }^{11}$ Если представители науки об обществе имеют основание полагать, что эмоционология уже «правит бал» в гуманитарном знании, то для историков данное направление научного поиска во многом остается исследовательской лакуной.

Однако следует отметить, что российскими историками еще до провозглашения создания науки об истории эмоций были созданы работы об эмоциях в истории. В 1971 г. в свет вышел сборник «История и психология» под редакцией Бориса Федоровича Поршнева. Б.Ф. Поршнев - автор выдержавшей несколько изданий монографии «Социальная психология и история» ${ }^{12}$.

Всплеск интереса к изучению психологических проявлений акторов истории наметился после смены исследовательских парадигм в конце XX - начале XXI в., когда на смену монополии марксистского (с приоритетами изучения политических и социально-экономических сфер) подхода пришел методологических плюрализм. В российской исторической науке появилось много новых подходов к изучению прошлого, в их числе - историко-культурная антропология. Так, в РУДН в 2000 г. был создан Межвузовский научный центр сопоставительных историко-антропологических исследований «Историко-антропологическая компаративистика», объединивший ученых из РУДН, ИВИ РАН, МГУ, РГГУ, ВШЭ и других вузов страны. В публикациях на страницах сборника «Ежегодник историко-антропологических исследований» разрабатывались различные подходы к интерпретации процессов и явлений социокультурной истории России, «специфики мировосприятия и культурно-поведенческих норм и стереотипов различных исторических эпох» ${ }^{13}$.

В тренде современной научной парадигмы с конца XX в. формировалось направление «интеллектуальная история». По мнению О. Нагорной, автора статьи из сборника «Диалог со временем», «история эмоций помогает более точно дать обоснования социальных и индивидуальных исторических феноменов» ${ }^{14}$. Лидер направления «интеллектуальная история» Л.П. Репина полагает, что важно, когда в «фокусе ... исследования оказывается внутренний мир человека, его эмоциональная жизнь» ${ }^{15}$.

На грани прошлого и нынешнего столетий в России плодотворно развивалась «историческая психология». Самые известные центры исследований: «се-

${ }^{11}$ Симонова О.А. Базовые принципы социологии эмоций // Вестник СПбГУ. Сер. 12. 2016. Вып. 4. С. 14.

${ }^{12}$ История и психология. Сборник. Москва: Наука, 1971; Поршнев Б. Социальная психология и история. Рига: Звайгэне, 1982.

${ }^{13}$ Козьменко В.M., Керов В.В. Межвузовский научный центр сопоставительных историкоантропологических исследований «Историко-антропологическая компаративистика» // Вестник Российского университета дружбы народов. Серия: История России. 2002. № 1. С. 118-119, 119.

${ }^{14}$ Нагорная О.С. «Полковник беззвучно зарыдал, слезы были на глазах у всех офицеров...» Коммуникация эмоций за колючей проволокой // Диалог со временем. 2011. № 35. С. 195-205.

${ }^{15}$ Репина Л.П. История исторического знания. Пособие для вузов. М.: Дрофа: Высшее образование, 2004. С. 266. 
верное общество» - Международная ассоциация исторической психологии имени В.И. Старцева (глава ассоциации - д.и.н. С.В. Полторак) и «южное общество» Междисциплинарный научный центр историко-психологических исследований (заведующая центром - д.и.н. С.С. Минц).

Наряду с исторической психологией проблемы проявления общественных настроений, коллективных и индивидуальных эмоций исследовали и другие отрасли историко-культурной антропологии: социальная история, новая персональная история или новая биографическая история, военно-историческая антропология, имагология.

Все перечисленные направления анализируют различные аспекты психологической матрицы прошлого, зачастую используя методологические подходы и методический инструментарий смежных дискурсов. Междисциплинарность несомненный плюс историко-культурной антропологии, частью которой является история эмоций.

Что касается современных «сенсорных» исторических исследований, то превосходным материалом для осмысления прошлого в дискурсе истории эмоций является полная драматизма история нашей страны. На документах российской истории немецкий ученый Уте Фревет (директор Центра по изучению эмоций при Институте человеческого развития Общества Макса Планка) исследовал динамику «возникающих» и «исчезающих» эмоций в истории.

Методология подобных научных изысканий формируется в отечественной историографии ${ }^{16}$. Обстоятельный обзор данных трудов дан в статьях И. Винницкого ${ }^{17}$, работах А. Зорина ${ }^{18}$, а также Я. Плампером, Ш. Шахадат и М. Эли в предисловии к сборнику «Российская империя чувств» ${ }^{19}$.

\section{Палитра женских чувств и эмоций в российском прошлом}

Вне сомнения, наиболее «эмоционально окрашенной» является гендерная и женская история. Поскольку формат статьи не позволяет рассмотреть проявление эмоций и мужчинами, и женщинами в изучаемый период, то автор ограничивается лишь анализом источников, вышедших из-под пера россиянок. Эмоции и чувства женской «половины» человечества в контексте мирового развития исследованы историками и литературоведами, политологами и гендерологами. Многие из них являются членами Российской ассоциации исследователей женской истории (РАИЖИ), которая проводит ежегодные конференции, выпускает сборники статей и материалов научных форумов. Дискуссионной площадкой для осмысления интеллектуальной истории в гендерном измерении являются сборники «Адам и Ева».

${ }^{16}$ Ливщин А. Настроения и политические эмоции в Советской России 1917-1932 гг. М.: РОССПЭН, 2010.

${ }^{17}$ Винницкий И. Заговор чувств или русская история на эмоциональном повороте... С. 441-460.

18 Зорин А. История эмоций. URL: http://polit.ru/article/2004/06/18/zorin; Зорин А. Появление героя: из истории русской эмоциональной культуры конца XVIII - начала XIX века. М.: Новое литературное обозрение. 2016.

${ }^{19}$ Российская империя чувств: Подходы к культурной истории эмоций. М.: Новое обозрение, 2010 . 
Отечественными историками хорошо изучены, прежде всего, такие традиционные психологические проявления женской идентичности, как милосердие, чувственность, сексуальность, и нетипичные, например, природа женской агрессивности.

Вне сомнения, гендерная идентичность строится, в числе многих других параметров, и на эмоциональной дифференциации. Однако, представления о том, какие чувства и эмоции «прилично» демонстрировать мужчинам и женщинам, могут меняться в зависимости от политической обстановки, культурных предпочтений эпохи, под влиянием этноконфессиональных конвенций и пр. Подобную эволюцию проявления чувств и эмоций в историософском ключе представил немецкий философ российского происхождения Иоганн Рay (J. Rau), обосновывая исторический характер человеческих чувств ${ }^{20}$.

Чтобы приступить в гендерному анализу эмоциональных характеристик эпох, необходимо оговориться, что гендерологи и историки не делают четкого разделения между эмоциями и чувствами, полагая, что всё это - «души изменчивой приметы» (Н.А. Заболоцкий). В этом - принципиальное отличие историков от ученых, занимающихся естественными и общественными науками. Но и в работах психологов и социологов существуют расхождения в понимании дефиниций «эмоции» и «чувства». В отношении чувств ученые сходятся во мнении о том, как их можно структурировать. Прежде всего, это моральные чувства (любовь - ненависть, симпатия - антипатия, уважение - презрение, привязанность - отчуждение, а кроме того, это - совесть, благодарность, дружба и пр.), которые обусловлены социальными коммуникативными практиками, нравственными нормами и устоями в обществе. Еще одна группа - интеллектуальные чувства: удовлетворение, радость, вдохновение, разочарование как «чувство горечи». Самые изысканные эстетические - чувства направлены на восприятие прекрасного (восторг, душевный подъем) или ужасного. Таким образом, чувства - это душевные состояния, а эмоции - это яркие (иногда очень непродолжительные) проявления чувств психические свойства.

Предметом острых дискуссий у представителей общественных наук является классификация эмоций. Психологи и социологи дают разные определения эмоций, спорят о том, какие из них являются базисными (и есть ли они вообще «основные» эмоции). Большинство российских и зарубежных психологов все же выделяет базисные эмоции (в разной «комплектации»): «страх», «удивление», «грусть печаль», «злость», «отвращение», «гнев» «восторг», «радость», «презрение». Иногда к эмоциям причисляют «стыд», «зависть» и даже «любовь». Однако, если быть точным, любовь - это не эмоция, а состояние, в течение которого человек может испытывать различные переживания: радость, умиление, эйфорию, ревность, тоску, грусть. Есть еще одно трудноуловимое эмоциональное состояние - счастье, где палитра ощущений столь же противоречива. Психологи выделяют «чистые эмоции» и «эмоциональные состояния»: переживания, ощущения, настроения, аффекты, страсти, стрессы.

${ }^{20}$ Pay И. О чувствах и эмоциях как предмете истории, философии и культурологии: очерк комплексной проблемы // Современная научная мысль. 2015. № 4. С. 109-118, 110. 
Таким образом, осмелимся предположить, что историк имеет дело чаще всего не с конкретными эмоциями и чувствами, а с эмоциональными состояниями: настроениями, как коллективными, так и с личными, переживаниями, чувствованиями, психологическими мотивами поступков, страстями, ощущениями. Следовательно, историк анализирует «состояние души», если дело касается индивидуума, и «дух времени», «атмосферу эпохи», «настроения», «ожидания» как составляющие менталитета или картины мира. Следует отметить, что у современных гендерологов не возникает сомнений, что женщине всегда была доступна вся палитра чувств и эмоций. Другое дело - могла ли женщина открыто демонстрировать свои психические состояния, или табуирование и предписания лимитировали их содержание и каналы трансляции? Поэтому для изучения гендерной специфики эмоций необходимо обращение к рассмотрению хронотопа, в рамках которого эти душевные переживания появлялись.

Если в отношении атрибуции психических концептов у философов, социологов и историков могут быть разногласия, то все гуманитарии сходятся во мнении, что эмоция - это реакция на внешний стимул, чаще всего на событие. Для историка здесь открывается важное поле деятельности - восстановить тот событийный ряд или ситуацию, которые привели к возникновению эмоций или чувств. Кроме того, необходимо посмотреть на ситуацию «глазами» носителя эмоций. Особенно это касается женщин, и не просто как биологического представителя пола, - во внимание стоит принять все факторы: возраст, социальное положение, этноконфессиональные аспекты и пр. Таким образом, изучать проявление женской «сенсорности» вне исторического, социального, культурного контекста невозможно.

\section{Первая мировая война как предмет изучения историками и гендерологами}

Одна из проблем, с которой неизбежно сталкивается исследователь прошлого - это наличие или отсутствие необходимых первоисточников. Кроме того, есть периоды, статичные по эмоциональному проявлению, например, средневековье. Оно достаточно «монотонно» и ритуализовано: в семиотическом плане нужно уметь «прочитать» внешние проявления внутреннего содержания, смысла демонстрируемых чувств. А есть эпохи, когда «страсти накаляются», даже «кипят», и проявление их носит характер «открытого митинга», демонстраций в прямом смысле слова. Самым высоким градусом эмоционального накала обозначен в российской истории, вне сомнения, период Первой мировой войны, особенно ее последний год, когда «термометр» эмоционального нагрева общества буквально «зашкаливало».

Эпоха Первой мировой войны достаточно хорошо осмыслена в отечественной и зарубежной историографии. Историками XX в. детально воспроизведен ход событий, написаны биографии военных и общественных деятелей, прослежены политические, экономические и социальные процессы, сопровождавшие ход военных действий. Переход к антропологической парадигме XXI в. позволил добавить «человеческий фактор», причем даже в полемику по поводу осмысле- 
ния такой сложной проблемы, как причины возникновения войны. Приверженцы военно-исторической антропологии среди причин агрессивности и войны стали называть психологические факторы в рамках биоционной и антропоционной концепций воинственности ${ }^{21}$.

Дискурсы военно-исторической антропологии и исторической психологии позволили историкам проследить различные проявления человеческого «Я» в военные годы: альтруизм, патриотические настроения, переживания, проявления военного пафоса. Учеными XXI столетия отмечено, что «переход от истории событий к истории опыта и “маленького человека" является характерной чертой современной историографии войн» ${ }^{22}$.

Следует отметить, что немало тем, связанных с событиями Первой мировой войны, было рассмотрено в рамках гендерного подхода. Ведущие специалисты по данной теме (Ю.Н. Иванова, П.П. Щербинин, Е.С. Сенявская, Н.Л. Матвеева, И.О. Дементьев, О.В. Большакова, Т.И. Трошина, О.И. Морозова, С.Д. Морозов, И.В. Перельман и другие) проанализировали степень участия женщин в боевых действиях и мобилизации «народного духа», выявили специфику женской благотворительности и особенности повседневной жизни женщин в тылу, проследили эволюцию ценностных ориентаций женского населения России ${ }^{23}$. Историками было «возделано» одно из главных проблемных полей женской истории периода мировой бойни: влияние войны на изменение положения женщин в обществе, на так называемый «гендерный порядок» ${ }^{24}$. Кроме того, очень болезненной и по сию пору дискутируемой является тема гендерных коммуникаций на фронте, в особенности один из ее аспектов - тема «телесности» и мужского насилия (причем не только со стороны врага).

Самое смелое исследование на данную тему проведено американским историком и антропологом Лори Стофф (L. Stoff). В ее последней книге, посвященной деятельности российских сестер милосердия, дан анализ отношения к медицинским сестрам со стороны общества, врачей, офицеров, солдат. Кроме того, исследовательницей представлена панорама визуализации (позитивной и негативной)

${ }^{21}$ Караяни А.Г. Психология войны: постановка проблемы с позиций военно-психологической науки // Военно-историческая антропология. Ежегодник. М.: РОССПЭН, 2002. С. 39-41.

${ }^{22}$ Поршнева О.С. Человек в условиях российской революции 1917 года: основные тенденции и достижения в изучении проблемы 1917 года в России: социалистическая идея, революционная мифология и практика. Екатеринбург: изд-во Урал. ун-та, 2016. С. 50-64, 55.

${ }^{23}$ Иванова Ю.Н. Храбрейшие из прекрасных: Женщины России в войнах. М.: РОССПЭН, 2002. С. 87-212; Щербинин П.П. Военный фактор в повседневной жизни русской женщины в XVIII начале XX века. Тамбов: Изд-во Юлис, 2004; Сенявская Е.С. Психология войны в ХХ веке. М.: РОССПЭН. 1999. С. 161-163; Морозов С.Д. Мужчины и женщины в России в годы Первой мировой войны: демографический кризис и потери населения // Женщина в российском обществе. 2014. № 3 (72). С. 10-20; Морозова О.М., Трошина Т.И. Женский взгляд на мужскую работу. Революция и гражданская война глазами и в судьбах женщин // Новейшая история России. 2016. № 2. С. 8-30.

${ }^{24}$ Перельман И.В. Влияние Первой мировой войны на развитие российского гендерного порядка. Феномен Марии Бочкаревой // Исторические, философские, политические и юридические науки, культурология и искусствоведение. Вопросы теории и практики. 2017. № 9 (83). С. 142-148. 
образов «сестричек», раскрыты другие «острые» гендерные проблемы ${ }^{25}$. Стоит согласиться с мнением гендерологов, что «российские исторические реалии представляют собой настоящую кладезь для историков гендера, особенно когда речь идет о Первой мировой войне» ${ }^{26}$. Уникальные документы эпохи представляют материалы периода мировой войны и исследователям истории эмоций.

\section{Источниковая база: проблемы отбора и интерпретации документов}

Поскольку исследовательская рефлексия должна основываться, прежде всего, на аутентичной и источниковой базе, цель данной статьи - проанализировать основные проблемы и перспективы использования письменных источников для реконструкции «психологического климата» в российском обществе периода Первой мировой войны с учетом гендерного фактора. Для проведения гендерной экспертизы данного отрезка российского прошлого в русле истории эмоций важно дать анализ основных категорий письменных источников, выявить степень репрезентации и способы трансляции чувств и эмоций в каждом из рассмотренных видов вербализированных (и письменно зафиксированных) свидетельств эпохи мировой войны.

Вне сомнения, для реконструкции гендерной специфики эмоционального ландшафта периода Первой мировой войны следовало бы привлечь все категории источников: устные, письменные, визуальные. Однако, во-первых, рамки статьи не позволяют этого сделать. Кроме того, каждый класс источников нуждается в самостоятельном рассмотрении, в том числе через призму истории эмоций. Поэтому для анализа был выбран самый солидный корпус документов - письменных.

Нарочито упускаем из дискурсивного анализа художественную литературу как вид исторического источника и делаем акцент на документальных свидетельствах. Из них для историков эмоций наиболее ценными являются источники личного происхождения: письма, дневники, записки, мемуары.

Как известно, к воспоминаниям, автобиографиям, мемуарам и иным формам интерпретационных источников отношение у «чистых» историков, историков культуры и литературоведов двойственное: как к источнику информации о прошлом и как к самостоятельному явлению женской письменной культуры. Филологи-востоковеды определяют мемориальный жанр как «женскую дневниковую литературу». Икеда Тцутому называет дневники придворных дам в Китае эпохи Хейан (IX-XII вв.) «ватакуси бунгаку» - «личной», «частной литературой» ${ }^{27}$. Рос-

${ }^{25}$ L.S. Stoff, They Fought for the Motherland: Russia's Women Soldiers in World War I and the Revolution (Kansas: University Press of Kansas, 2006); L.S. Stoff, Russia's Sisters of Mercy and the Great War: more than binding men's wounds (Kansas: University press of Kansas, 2015); Мицюк Н.А., Пушкарёва Н.Л. «Не только перевязка мужских ран»: историко-антропологическое исследование медицинского сестринства в годы Первой мировой войны // Сибирские исторические исследования. 2018. № 2. C. 244-252.

${ }^{26}$ Большакова O.B. Проблемы и перспективы гендерной истории Первой мировой войны. URL: http://legacy.inion.ru/index.php?page_id=534.

${ }^{27}$ Гафурова Х.Ш. Некоторые критерии жанровой идентификации средневековых японских дневников // Молодой ученый. 2011. № 6. С. 15-17. 
сийской женской мемуаристике присуща особая лиричность, исповедальность, но в то же время и публицистичность. В данном случае для исследователя важны обе данные характеристики. С точки зрения реконструкции событий, по мнению авторитетных ученых-гендерологов, «историку ... всегда важны и более ценны рефлексии по поводу свершившихся событий» самих участников исторической драмы $^{28}$. А для воссоздания истории женских эмоций важны гендерно-чувствительные свидетельства «из первых уст», причем чем «эмоциональнее» они написаны, тем лучше. Кроме того, для воспроизведения подлинной картины событий, как отмечают те же исследователи, важнее написанные спустя некоторое время воспоминания, где уже «улеглись эмоции» и есть возможность «здраво» оценить происходившее, описать его с учетом факторов, о которых автор записок мог и не знать в момент фиксации материала. Для воссоздания сиюминутной атмосферы исторического «момента», напротив, важнее «репортажи с места событий»: дневниковые записи, письма, путевые заметки.

Весьма сложно оценить значимость для данного исследования такого своеобразного, с ярко выраженной гендерной спецификой жанра еgо-документа, как женские автобиографии, или, как их принято называть в гендерном дискурсе, «автогинографии». Их анализ детально проведен в публикациях Н.Л. Пушкаревой ${ }^{29}$. С одной стороны, любая женская автобиография - это демонстрация искусства самопрезентации, следовательно, текст может отображать действительность искаженно, с целью «приукрасить» роль автора в событиях. С другой стороны, поскольку речь идет о собственной персоне, то это, как правило, наиболее наполненный чувствами текст, так как даже дамы с самоиронией, желая преподнести себя «в выгодном свете», дают детальную «отработку эмоций».

Перед исследователем всегда стоит проблема отбора источников. В советское время историки вынужденно проводили ранжирование создателей автодокументальных текстов - от «выдающихся исторических личностей, сумевших отразить мысли и переживания многих людей до людей рядовых, а потому... не слишком интересных» ${ }^{30}$. Однако для воссоздания картины человеческих переживаний в период социальных катаклизмов важно просмотреть весь спектр репрезентаций, калейдоскоп эмоций, звучащих из дворцов, окопов, госпиталей, деревенской глубинки, заводов, студенческих кампусов. По мнению современных историков, «не столько усилия политической элиты или революционных вождей, сколько социокультурные стереотипы сознания и поведения народных масс ... повлияли на характер трансформации российского общества» в период Первой мировой войны ${ }^{31}$.

${ }^{28}$ Пушкарёва Н.Л. Публичное вторжение в частную жизнь (эвристическая ценность устных и письменных эго-документов для гендерной истории) // Запад - Восток. 2018. № 11. С. 161-179, 163.

${ }^{29}$ Пушкарёва Н.Л. У истоков женской автобиографии в России // Филологические науки. 2000. № 3. С. 62-70; Пушкарёва Н.Л. Мемуары и автобиографии женщин как исследовательский «полигон» для изучения «женского письма» // Е.Р. Дашкова и XVIII век. Традиции и новые подходы. М.: МГИ им. Е.Р.Дашковой, 2012. С. 224-241.

${ }^{30}$ Голубциов В.С. Мемуары как источник по истории советского общества. М.: Издательство Московского университета, 1970. С. 44.

${ }^{31}$ Поршнева О.С. Крестьяне, рабочие и солдаты России накануне и в годы Первой мировой войны. М.: РОССПЭН, 2004. С. 3-4. 
Между тем комплекс опубликованных источников, которые позволили бы реконструировать ментальные установки и социально-психологическую атмосферу эпохи, представлен неравномерно, в отличие от документальной базы по экономическому и политическому развитию страны. Если вернуться к марксистской классовой концепции, то следует сделать вывод, что большинство источников озвучивает эмоциональный фон только «с одной стороны баррикад». Причина тому - история формирования корпуса источников.

В 1920-1930-х гг. благодаря деятельности зарубежных эмигрантских центров, в частности Русского заграничного исторического архива (РЗИА) при Министерстве иностранных дел Чехословацкой республики, были собраны огромные коллекции документов личного происхождения россиян, оказавшихся за пределами родины. Среди них - дневники, переписка, воспоминания о периоде Первой мировой войны в России. Целью сбора данных документов было желание представить период революции, гражданской войны и период 1914-1918 гг., поскольку мировая война мыслилась неотделимой частью этих событий. Сегодня так называемая «белогвардейская коллекция» Пражского РЗИА находится в Государственном архиве Российской Федерации. Еще более весомая часть семейных архивов и частных коллекций российских эмигрантов хранится в США, в Станфордском университете в Архиве Гуверовского института войны, революции и мира (Hoover Institution Archives Holdings on Russia). На документах данных коллекций строят свои исследования зарубежные историки, реконструируя женские судьбы периода Первой мировой войны ${ }^{32}$.

\section{Женские «эмоциональные сообщества» в России в 1914-1918 гг: попытка классификации}

Для того, чтобы представить, как «озвучены» эмоции по социальному и иному статусу, попытаемся провести классификацию и отчасти ранжирование женских «эмоциональных сообществ» россиян. Концепция «эмоциональных сообществ» представлена наиболее полно в работах историка-медиевиста Барбары Розенвейн (B. Rosenwein). Исследовательница выделяет сообщества «социальные» (нормативные) и «текстуальные», основанные на единстве идеологии, отмечая при этом, что одни и те же люди могут входить в разные эмоциональные сообщества ${ }^{33}$.

Российское общество начала XX в., и в особенности периода Первой мировой войны, действительно, можно представить как галактику эмоциональных сообществ, как гендерно-паритетных, так и моносексуальных, например, женских. Ранжирование или просто классификация по признаку социальной стратификации и «слышимости» голосов в истории, по степени и способам трансляции тек-

${ }^{32}$ Pannanopm X. Дневники княжон Романовых. Загубленные жизни / Пер. с англ. И. Мовчан. М.: Издательство «Э», 2015. С. 588-589; Pannanopm X. Застигнутые революцией. Живые голоса очевидцев / Пер. с англ. И. Мовчан. М.: Издательство «Э», 2017. С. 495-496.

${ }^{33}$ Симонова О. Изучение эмоций как область междисциплинарной интеграции: история и социология в поисках объяснения «эмоционального поворота». К выходу русского перевода книги Яна Плампера «История эмоций» // Социологическое обозрение. 2018. Т. 17. №. 3. С. 356-378. С. 362. 
стов эмоций и репрезентативности источников, в которых они зафиксированы, позволяют выделить четыре уровня эмоциональных сообществ россиянок.

К первой категории эмоциональных сообществ следует отнести представительниц правящего до марта 1917 г. Дома Романовых и их аристократическое окружение. Часть женщин из «верхушки общества» входила в другое эмоциональное сообщество - «фронтовички», куда входили и медицинские работники: немногочисленные женщины-врачи, самая массовая группа - сестры милосердия и хозяйственный персонал лазаретов и госпиталей. Из данной статьи намеренно исключен анализ одной из субкультур эмоционального сообщества «фронтовичек» - доброволиц, поскольку данная тема достаточно хорошо изучена с точки зрения источниковедения, исследования эмоций самих героинь и по отношению к ним. Таковы закономерности науки: казусы наименьшей, но атипичной группы могут вызывать больший интерес, нежели жизнь самых многочисленных сообществ. Это характерно и применительно к России начала XX в., где работницы и крестьянки представлены с точки зрения эмоций наименее всего. Пролетарки входили особой группой в третью категорию эмоциональных сообществ - городских жительниц, хотя многие из них занимали маргинальное положение, будучи выходцами из крестьян. Кроме того, большинство из них было солдатками. Жительницы сельской местности, на плечи которых легла основная нагрузка военных лет, составляют четвертый уровень, также достаточно неоднородный по составу и восприятию войны. Однако подавляющее большинство крестьянок, наряду работницами и горожанками, входило в сообщество «солдаток».

Мировая война изменила жизнь всех слоев населения России. Возможно, меньше всего физической и психологической нагрузки пришлось на долю женщины высшего общества. Документы личного происхождения данного эмоционального сообщества опубликованы в достаточной мере; обширные фонды материалов находятся в центральных российских и зарубежных архивах. Особенно это касается представительниц императорской семьи: их переписка, мемуары, дневниковые записи помогают воссоздать картину реальных событий и испытываемых чувствии и эмоций.

Наиболее детально представлен период 1914-1918 гг. в дневниках вдовствующей императрицы Марии Федоровны ${ }^{34}$. Это - уникальный источник для выявления отношения самой вдовствующей императрицы к событиям, происходившим в стране и мире. Однако сама война в ее записях - это скорее «отголоски событий». Она воспринимает происходящее опосредованно, через мнения близких ей людей, иногда - из прессы. Кроме того, ее эмоции весьма сдержаны, однолинейны и статусно ангажированы. Она «оживляется» лишь, когда речь заходит о членах ее семьи и друзьях. Все это описано более трогательно, остальное - как бы «по обязанности». При этом к ней, датчанке, в обществе относились лучше, нежели к императрице Александре Федоровне, немке по происхождению.

Из мемуаров других представительниц дома Романовых по степени проявления эмоций в рефлексии войны можно выделить записки великой княгини Ма-

\footnotetext{
34 Дневники императрицы Марии Федоровны (1914-1920, 1923 годы). М.: Вагриус, 2005.
} 
рии Павловны (младшей) ${ }^{35}$. Ее воспоминания, записанные уже в зрелые годы, многократно переиздавались, сменив «говорящее» название «Education of princess» ${ }^{36}$ на более нейтральные.

Следует отметить, что Мария Павловна вернулась в Россию накануне мировой войны, пережив личную драму, однако не замкнулась в себе, а напротив, разделила с согражданами «возвышенный патриотизм». Несмотря на то, что она наблюдала во дворце различное восприятие войны («руки в длинных белых перчатках нервно комкали носовые платочки», «мужчины глубокомысленно хмурили брови, переминаясь с ноги на ногу») Мария, с присущей юной особе романтизмом, была уверена, что «чувство национальной преданности, национального единства было искренним» ${ }^{37}$.

Мария Павловна провела большую часть военного времени в прифронтовом госпитале в Пскове и потому может быть причислена и ко второму эмоциональному сообществу - «фронтовичек». Ее записки - блестящий источник по истории эмоций. Важно и то, что она писала их собственноручно, в отличие, например, от записок сестры императора великой княгини Ольги Александровны. «Последняя великая княгиня» Романова диктовала свои воспоминания в эмиграции Яну Ворресу $^{38}$. Еще одна подобная «автобиография», также переданная другим человеком - биография императрицы Марии Федоровны, неоднократно переиздавалась на английском языке, однако материалы данного источника практически не используются отечественными исследователями ${ }^{39}$. Эти и другие мемуары членов императорской семьи позволяют почувствовать атмосферу дворца, менявшуюся от состояния эйфории в начале войны до ощущения катастрофы и апокалипсиса в конце периода.

Еще одной категорией источника с высокой степенью демонстрации эмоций является переписка. Важно то, что письма фиксируют возникающие эмоции и детали событий, которые, по прошествии времени, могут стереться из памяти. Особенно значимы для историка эмоций женские письма, которые всегда наполнены чувствами и переживаниями, так как функции женской памяти связаны более с эмоциональным восприятием событий, нежели с их сюжетной стороной. Кроме того, в отличие от мемуаров, письма всегда более откровенны, интимны, особенно если они адресованы близкому человеку. Примером такого источника может служить переписка супругов Николая II и Александры Федоровны.

Письма были обнаружены в Екатеринбурге после расстрела царской семьи. Часть писем (копий) попала за рубеж и была в 1922 г. опубликована в Берлине.

35 Дочь великого князя Павла Александровича, сына Александра II и греческой принцессы Александры Георгиевны.

${ }^{36}$ Education of princess. A memoir by Marie, Grand duchess of Russia. Translated from French and Russian under the editorial supervision of Russel Lord (New York: The Viking press, 1980).

${ }^{37}$ Воспоминания великой княгини Марии Павловны. М.: Захаров, 2004. С. 141.

${ }^{38}$ The last Grand-Duchess. Her Imperial Highness Grand-Duchess Olga Alexandrovna. 1 june 1882 - 24 November 1960. Ian Vorres (London: Hutchinson of London, 1964).

${ }^{39}$ Hall, Coryne. Little mother of Russia: a biography of the Empress Marie Feodorovna (1847-1928) (London: Shepheard-Walwyn, 1999, 2006). 
Несмотря на то, что данный источник нуждается в проверке достоверности, переписка широко используются в исторической литературе. Для историка эмоций эти послания интересны, например, возможным выявлением мотивов благотворительной деятельности императрицы. Были ли ее проявления эмпатии к находящимся на излечении в ее образцовых лазаретах бойцам искренни? Ответ на данный вопрос затруднен тем, что императрица была сдержанна в публичном проявлении чувства и эмоции, и зачастую лишь письма передают ее переживания. Историки расходятся во мнении: благотворительная деятельность Александры - это дань ей протестантским и семейным традициям филантропии, попытка завоевать популярность (исторический казус: императрица-немка возглавила женское патриотическое движение - лишь подогревал германофобию в обществе) или проявление истинного сострадания? Александра Федоровна пишет Николаю II, что ее работа в госпитале, особенно уход за тяжелоранеными, - ее утешение ${ }^{40}$. И потому ряд исследователей небезосновательно полагает, что мотивы благотворительной деятельности императрицы заключались «более всего в том, чтобы облегчить свою тоску и печаль» ${ }^{41}$. Императрица, действительно, пыталась таким образом «скрасить» свои страдания от разлуки с мужем, однако при этом действенно проявляла милосердие. О масштабах ее помощи фронту и фронтовикам свидетельствуют материалы архивов ${ }^{42}$.

Документы архивов демонстрируют и активное проявление эмпатии сестры императрицы, великой княгини Елизаветы Федоровны ${ }^{43}$. Деятельность ее комитета поистине беспрецедентна: во время войны Елизаветинский комитет организовывал помощь раненым по всей стране. Документы, связанные с личностью и деятельностью настоятельницы Марфо-Мариинской обители, частично опубликованы $^{44}$.

Следует отметить, что в РГИА, ГАРФ, РГВИА (Российский государственный военно-исторический архив) находится множество не введенных в научный оборот свидетельств данной эпохи, способных помочь в реконструкции общественных и индивидуальных эмоций данного сообщества: это переписка, фотоальбомы, наброски путевых заметок, камер-фурьерские журналы и многое другое. Все это более «правдивые» и искренние документы, нежели мемуары. Например, можно сравнить опубликованные воспоминания сестры Николая II Ольги

${ }^{40}$ Письма императрицы Александры Федоровны к императору Николаю II. Берлин: Слово, 1922. C. 30 .

${ }^{41}$ Максимова Ю.О. Письма Александры Федоровны к Николаю II Александровичу как источник для осмысления мотивации благотворительной деятельности императрицы в 1914 г. // Ars Historiса. Проблемы интерпретации исторических источников. 2017. С. 115-120, 119.

42 Государственный архив Российской Федерации (далее - ГАРФ). Ф. 640. Оп. 1. Д. 13. Л. 1-38; ГАРФ. Ф. 640. Оп. 1. Д. 28. Л. 1-56; Российский государственный исторический архив (далее РГИА). Ф. 525. Оп. 6. Д. 433, 448, 517.

${ }^{43}$ Иванова Е.В. Реконструкция комплекса архивных материалов о благотворительной деятельности великой княгини Елизаветы Федоровна // Вестник архивиста. 2013. № 3. С. 101-112.

${ }^{44}$ Материалы к житию преподобномученицы великой княгини Елизаветы. Письма, дневники, воспоминания, документы. М.: Сестричество во имя преподобномученицы великой княгини Елизаветы: Отчий дом, 1996. 
Александровны и ее письма сестре Ксении из ГА РФ. В мемуарах великая княгиня раскрывает канву событий, а в письмах сестре описывает глаза умирающих «солдатиков». Ольга Александровна работала в госпитале в Киеве, ассистировала на самых сложных операциях и не покидала госпиталь даже после падения самодержавия, когда семья Романовых уже подверглась гонениям. В письмах сестре Ксении в марте 1917 г. - ее тревога за арестованных брата и его семью, но более всего - за судьбу страны.

Ситуация парадокса происходила в годы мировой войны и в эмоциональной жизни Ольги Александровны: она покинула ненавистный дворец, вышла замуж за «простого офицера» и ощутила себя абсолютно счастливой в период государственный катаклизмов, родив одного ребенка в 1917 г., второго - в 1919 г. Таким образом, история личных чувств не всегда совпадает с эмоциями своего сообщества, общественными настроениями и «духом времени».

Еще больше демонстрации удовлетворенностью жизнью и даже счастья, как это не покажется парадоксальным, исследователь найдет в источниках, исходящих из второй группы эмоциональных сообществ, - женщин, непосредственно помогающих фронту, и участниц фронтовой жизни. Это - дамы, которые не только финансировали санитарные поезда и лазареты, но и принимали в их работе непосредственное участие. Но самые ценные «человеческие проявления» находятся на страницах мемуаров сестер милосердия.

В текстах их воспоминаний и записок много элементов документализации мы можем проследить по ним положение дел «на театре военных действий», настроение офицеров и солдат, увидеть изнанку войны, почувствовать проявление таких не очень свойственных женщинам эмоций, как «злость», «гнев», «ненависть», «отвращение». По социальному происхождению авторы текстов чаще всего аристократки, дворянки, студентки женских курсов, представительницы творческих профессий (актрисы, балерины). Во-первых, в их среде принято было вести дневники и писать письма (а на их основе создавались затем воспоминания). Во-вторых, в силу занятости крестьянки и работницы не могли посвящать свое время волонтерству, они оказывали помощь фронту «профессионально», обеспечивая себя и семью. И уж точно им некогда было писать что-то помимо писем.

Для исследователя такие источники, как записки и воспоминания «фронтовичек», чрезвычайно важны, так как они позволяют проследить эволюцию мироощущения автора на протяжении всего периода войны. За последние десятилетия в российском информационном пространстве появилось немало таких текстов, например, женские фронтовые мемуары ${ }^{45}$. Историк Дарья Болотина, автор вступительной статьи к запискам Х. Семиной, отмечает, что «записки ее достаточно

${ }^{45}$ Варнек Т.А. Воспоминания сестры милосердия (1912-1922). URL: www.dk1868.ru/history/varnek/varnek1.htm; Семина Х.Д. Записки сестры милосердия: Кавказский фронт. 1914-1918 гг. М.: Кучково поле, Горные технологии. 2016; Игельстром А. Воспоминания о Первой Мировой войне Ольги Григорьевны Федюкиной-Имберх // Проза. Ру. URL: https://www.proza.ru/2017/08/26/1230 (дата обращения: 12.01. 2019); Записки сестры милосердия Анны Ждановой. Тверь: Триада, 2014; Фармборо Ф. Первая мировая война. Дневники с фронта. М.: ОЛМА Меда Групп, 2014; Быть сестрой милосердия. Женский лик войны. М.: Алгоритм, 2017. 
интимны, ...изображаемые в них события эмоционально окрашены и передаются в индивидуальном восприятии и оценке» и это позволяет «уловить подлинный смысл «живой жизни», который «прочувствован и отражен в личных записках» ${ }^{46}$. Эта характеристика может быть отнесена к произведениям всех авторов.

Свидетельницы событий, авторы мемуаров передают атмосферу времени, например, могут представить историческое пространство как живой организм, транслирующий собственные эмоции: «Москва из патриархального, спокойного, тихого города превратилась в напряженный и мечущийся организм. В воздухе чувствовалось какое-то напряжение, все ждали чего-то необычайного! ${ }^{47}$.

На деле в Москве происходило то, что петербургский историк Б.И. Колоницкий определил как «демонстрация специфического патриотизма военной поры» ${ }^{48}$, но романтизация - особенная черта женских мемуаров военной поры. Поэтому данную позицию сентиментальной «пишбарышни» интересно сравнить с другим видением войны, транслирующим циничный взгляд зрелой женщины. Для сравнения могут быть выбраны мемуары Татьяны Варнек, юной девушки, отправившейся на фронт в качестве сестры милосердия военного времени, и записки литератора Зинаиды Гиппиус. Например, вот отклик Гиппиус на патриотическую эйфорию первых недель войны: у Зинаиды Гиппиус этот массовый, во многом «показушный», энтузиазм вызывает отвращение: «Мне жалки эти ...“патриотические” демонстрации с хоругвями, флагами и “патретами”. Москва в повальном патриотизме, с погромными нотками». «Москвичи осатанели от православного патриотизма» ${ }^{49}$. Тем не менее ей, наблюдавшей войну из окна своего дома и потому питавшейся зачастую мифами и слухами, не всегда были доступны истинные проявления лика войны, и география ее эмоций не распространяется дальше двух столиц, хотя она часто употребляет понятия «Россия», «страна», «народ». Все же понять, что происходило в стране и на фронте могли лишь те, кто вышел за пределы привычной среды обитания.

В рассмотрении феномена «женщина на фронте» и для историка, и для психолога интерес представляет мотивация поступков героинь. Что влекло в зону риска (в том числе гендерного) женщин в Первую мировую войну: чувство долга, понятие чести, романтика, жажда подвига и славы, тщеславие, любопытство, сенсорный голод? Или многие из них, действительно, отправились на фронт «за женихами»?

Для ответа на данный вопрос представляется интересным сравнить мемуары (такие аспекты, как мотивы мобилизации и эмоции в момент попадания на фронт, особенности повседневной жизни, коммуникативные гендерные практики, восприятие противника и пр.) медицинских сестер, участвовавших в разных войнах России.

${ }^{46}$ Семина Х.Д. Записки сестры милосердия: Кавказский фронт. 1914-1918 гг. М.: Кучково поле; Горные технологии. 2016. С. 5. Имберх...

${ }^{47}$ Игельстром А. Воспоминания о Первой Мировой войне Ольги Григорьевны Федюкиной-

${ }^{48}$ Колоницкий Б.И. Революция 1917 года. М.: Эксмо, 2018. С. 10.

${ }^{49}$ Гиппиус 3.Н. Дневники. URL: http://az.lib.ru/g/gippius_z_n/text_0070.shtml (дата обращения: 11.01.2019) 
Опыт фронтовой жизни у части россиянок был и до Первой мировой войны. Сестры милосердия под эгидой Красного Креста оказывали помощь воинам на полях сражений в ходе войн России с Турцией, Японией, в ходе Балканских войн 1912-1913 гг. Участвовали женщины как равноправные воины и медицинский персонал в советско-финляндской и Второй мировой и Великой Отечественной войне. Намеренно (по этическим мотивам) исключаем из этого списка войну гражданскую.

Среди авторов, оставивших свои воспоминания о фронте периода Первой мировой, были «патроны» санитарных поездов и военных лазаретов, и рядовые медицинские сестры. Рефлексия последних по поводу войны наиболее важна они находились в эпицентре событий, как и медицинские сестры периода следующей мировой войны ${ }^{50}$.

Следует отметить, что женщины периода Второй мировой были более подготовлены и физически (их поколение прошло школу «Ворошиловских стрелков»), и психологически. Девушки начала XX в. явно не представляли себе реалий фронта. Они могли наивно радоваться встрече с новой жизнью: «Отъехали под громкие крики «ура!» ... в купе... диваны были завалены шоколадом, конфетами и цветами» ${ }^{51}$. Второй вариант - испытывали страх при приближении к линии фронта: «Почему мне как-то жутко? Чем ближе к фронту, тем тоскливее! ...чувствую, ...точно что-то затягивает» ${ }^{52}$. Испытывали страх «сестрички» и во время сражений, рассказывая об этом без стеснения: «Немиь стали отвечать, сначала из ружей, потом из пушек ... и стало страшно по-настоящему. Побежали ... обратно, стараясь не показывать друг другу дрожащие руки». «Было страшно, не скрою, сердие иной раз холодело и останавливалось» ${ }^{53}$.

Очень часто фигурирует в описаниях состояние нервного напряжения, особенно при работе в полевом госпитале. Маргинальное состояние госпиталя - между экстримом фронта и расслабленностью тыла - позволяло лучше осознавать происходящие события, анализировать отношения между людьми. Однако для медицинских сестер не всегда было понятно, что окружающие их люди - временные; зачастую формировалась привязанность между «сестричками» и ранеными или врачами, а затем следовало болезненное расставание. И эти личные отношения были более важны для женщин, нежели действия самой войны.

Однако госпиталь - это еще и состояние между жизнью и смертью. Непрекращающиеся операции, грязь, эпидемии, обстрелы, - все это порождало нервное перенапряжение. «Я была ... взбудоражена от всего этого: ... от человеческих страданий, от запаха крови и гноя» ${ }^{54}$.

${ }^{50}$ Акишина С.Н., Беланова А.М., Зверкова Н.С., Беляков Н.А. Сестры милосердия в России. Начало XIX - начало XX века. М.: Альянс, 2014.

${ }^{51}$ Варнек Т.А. Воспоминания сестры милосердия...

${ }^{52}$ Семина Х.Д. Записки сестры милосердия... С. 65.

${ }^{53}$ Игельстром А. Воспоминания о Первой Мировой войне Ольги Григорьевны ФедюкинойИмберх...

${ }^{54}$ Там же. 
Механизмы адаптации к реалиям фронтовой жизни у женщин были различны. Во-первых, попытки «забыть весь этот кошмар», «ужас» ${ }^{55}$ или «убрать нервы»: «Нервы на войне были притуплены, и переживалось всё не так, как в обычное время» ${ }^{56}$. Но главное «оружие» фронтовых сестер в борьбе с негативными эмоциями - оптимизм. «Молодость и желание жить заставляли нас легкомысленно относиться ко всему, даже к самым серьезным вещзам» ${ }^{57}$.

Кроме еgо-документов есть и другие источники, которые позволяют реконструировать психологический климат внутри микроколлективов военного времени. Так, в таких архивах, как ГА РФ, РГИА, более всего - РГВИА, хранятся документы, связанные с деятельностью лазаретов и госпиталей. Зачастую это просто «сухие отчеты» по техническому оснащению, финансовому, кадровому положению лазаретов, но иногда и достаточно «живые» источники. Таков, например, отчет врача Любомира Боровского, заведующего лазаретом Доротеи Эдуардовны и Альбрехта Георгиевича Радзвиллов в Несвижском замке. Доктор пишет о том, что женщины готовы служить родине «с великой радостью и сердцем переполненном любовью и нежностью к раненому русскому воину». «С объявления этой чрезвычайно популярной войны... каждая женщина жадно искала приложения накопившейся... общественной энергии... для служения Родине в эту захватывающую историческую минуту» ${ }^{58}$.

Следует отметить, что подобная патетика была присуща документам начала XX в., но, тем не менее, в данном документе отражены общественные настроения женщин в начале войны и отношение к женщинам, которое за годы войны существенно изменилось. Особенно это коснулось тех, кого в начале войны называли «заслуженным и высоким именем сестрицы». Архивные материалы и источники личного происхождения позволяют проследить эволюцию отношения к медицинским сестрам за период войны.

С одной стороны, известно, что в России к медицинским сестрам относились более доброжелательно, нежели в войсках союзников. Это подтверждают мемуары английских сестер милосердия, служивших в России, и архивные материалы. Например, в 1916 г. во Францию был отправлен отряд сестер милосердия для работы в госпиталях, где проходили лечение раненые российские воины. По сообщениям руководительницы отряда, старшей сестры милосердия Общины Св. Георгия Александры Вадимовны Романовой, «отношение сестер к солдатам и уважение и любовь, с которыми солдаты относятся к сестрам, удивляло французов ${ }^{59}$. Военный антрополог Е.С. Сенявская, исследуя феномен женщины на войне, приходит к выводу, что военные относились в слабому полу неоднозначно: к женщинам, стремившимся попасть на фронт, они испытывали недоверие,

${ }^{55}$ Семина Х.Д. Записки сестры милосердия... С. 184. Имберх...

${ }^{56}$ Игельстром А. Воспоминания о Первой Мировой войне Ольги Григорьевны Федюкиной-

57 Там же.

${ }^{58}$ ГАРФ. Ф. 642. Оп. 1. Д. 421. Л. 9.

${ }^{59}$ Российский государственный военно-исторический архив (далее - РГВИА). Ф. 12651. Оп. 1. Д. 554. Л. 105 об. 
скептицизм, а к сестрам милосердия, напротив, проявляли сочувствие, опеку ${ }^{60}$. Мемуары фронтовых медсестер полны воспоминаниями об «обожании, которым окружали» «сестричек» в первые годы войны ${ }^{61}$. Тем не менее, кроме восхищения женским подвигом милосердия (предполагалось, что «служение сестер безвозмездно и бескорыстно» ${ }^{62}$ ), с течением времени в российском обществе появлялись и другие настроения. В записках сестер милосердия меняется тон: воспоминания последних лет войны сродни репортажам с театра военных действий, где шло не только противостояние врагу, но и «борьба полов», отстаивание чести и преодоление кризисов гендерной идентичности.

Историки называют ряд причин, почему «платье сестры милосердия» стало «знаком измены и разврата» ${ }^{63}$. Не вступая в дискуссию о «фронтовой женофобии», согласимся с исследователями данной темы в том, что «так порожденные войной чувства вызывали трансформации социума» ${ }^{64}$.

В следующую категорию женских эмоциональных сообществ входили городские жительницы. Спектр данных микро-сообществ достаточно широк: это дворянки, мещанки, студентки, представительницы творческой интеллигенции, работницы заводов и фабрик ${ }^{65}$, служанки и пр. «Разноголосица» их чувств и эмоций в военное время частично представлена записками и воспоминаниями, но в большей степени отражена в материалах женских журналов, студенческих анкетах, документах региональных архивов.

В начале XX в. в России было несколько видов женских изданий. Женские журналы периода мировой войны отличались по степени репрезентации эмоций. Самыми «громкими» были партийные издания для пролетарок («Работница», «Доля Работницы»), где звучала критика существующего порядка, войны и проецировались четкие политические и социальные позиции гражданок. Более умеренными по звучанию были издания феминисток («Женский вестник», «Женская жизнь», «Женское дело»). Они вели летопись женского движения, обсуждали проблемы женского труда, положения женщины в семье, обществе и государстве; публиковали биографии выдающихся женщин, женскую беллетристику и поэзию. В последних разделах журналов помещалась хроника культурной жизни страны. Здесь превалировали «новые» женские ценности: феминизм, суфражизм. Обсуждение вопросов личной жизни переходило в плоскость рассмотрения природы

${ }^{60}$ Сенявская E.C. Психология войны в ХХ веке: исторический опыт России. М.: РОССПЭН, 1999. C. 145.

${ }^{61}$ Варнек Т.A. Воспоминания сестры милосердия...

${ }^{62}$ РГВИА Ф. 12651. Оп. 1. Д. 546. Л. 6 об.

${ }^{63}$ Колоницкий Б.И. Образ сестры милосердия в российской культуре эпохи Первой мировой войны // Большая война России: социальный порядок, публичная коммуникация и насилие на рубеже царской и советской эпох: сборник статей. М.: Новое литературное обозрение, 2014. С. 100-126.

${ }^{64}$ Дементьев И.О. Современная историография о гендерных аспектах истории Первой мировой войны // Вестник Балтийского федерального университета им. И. Канта. Серия: Гуманитарные и общественные науки. 2014. №12. С. 84-93.

${ }^{65}$ Белова T.B. Социальное положение женщин-работниц в губерниях Верхнего Поволжья в годы первой мировой войны // Женщины и российское общество: научно-исторический аспект. Иваново: изд-во Ивановского Государственного Университета, 1995. С. 77-81. 
сексуальности, что было весьма революционно для того времени. Проблемы домашнего быта, фасоны модных нарядов, реклама товаров - все это считалось недостойным размещения в журналах российских «равноправок».

Но была и третья категория изданий, где публиковались «эмоционально окрашенные» материалы на тему войны, положения женщины в семье и обществе. Здесь пропагандировались вечные ценности: любовь к ближнему, подвижничество, вера, смирение и очень осторожно проводилась «линия на освобождение» от зависимости семейного бремени. Именно третья категория женских изданий - журналы для домохозяек периода военного времени - демонстрирует корреляцию автостереотипов и вербальной самоидентификации российских женщин. Стиль статьей данных журналов был эмоционален; публикации полны вербальных демонстраций удивления, восхищения примерами героизма российских женщин и их союзниц «на театре войны». Изменился и арсенал вербальной презентации внутреннего самоощущения российских женщин, - все чаще на страницах дамских изданий звучат слова «либеральный», «свободомыслящий», а применительно к себе женщина озвучивает понятие «новая». Под воздействием войны появляется лексика, отражающая психоз, безумие войны (для врага находились самые жесткие эпитеты: «варвар», «зверь», «изверг», «злодей», «скот», «свинья»). В содержании текстов и «способах говорения» много патетики. Материалы таких изданий, как «Мир женщины», «Журнал для хозяек», «Женщина и война», позволяют провести психосемантический анализ текстов и проследить то, как менялась тональность публикаций от 1914 к 1917 гг. ${ }^{66}$

Еще одной группой источников, где были вербализированы «движения души» россиянок, являются «самопереписи» студенток женских курсов. Данный «опыт самообследования» был проведен «статистическим семинарием» Бестужевских курсов в конце октября 1915 г. ${ }^{67}$ В анкетных листах девушки не просто писали об условиях жизни, но и «изливали» свои эмоции.

Анкеты курсисток могут служить превосходным материалом для изучения эмоционального настроя студенческой молодежи и психологических стратегий выживания в период войны. Хроническая финансовая нужда, «квартирный вопрос», дефицит продуктов питания и топлива, чудовищная инфляция, необходимость иметь заработок, - все это приводило к физическим и психологическим перегрузкам и профессиональным заболеваниям - «академическому травматизму».

Основным приемом адаптации к реалиям военного времени была самоирония. Студенки - «одинокие пионерки, заехавшие в Петербург», вспоминали, что они «относились к материальным невзгодам с той веселой иронией, которая возможна лишь в лета юности» ${ }^{68}$.

${ }^{66}$ Синова И.В. «В свободной России не должно быть прежней женщины-рабы», или о чем писали отечественные журналы в 1917 г. // Женщина в российском обществе. 2014. № 3 (72). С. $98-106$.

${ }^{67}$ Слушательницы Петроградских высших женских (Бестужевских) курсов на втором году войны. Бюджет. Жилищные условия. Питание. По данным переписи (анкеты), выполн. Стат. Семинарием в конце окт. 1915 г. Петроград: [Б.и.], 1916. C. $87-88$.

${ }^{68}$ Некрасова Е. Из прошлого женских курсов. М.: издание типографии А.А. Карцева, 1886. 
Таким образом, городская среда столиц порождала разнородные культурные тексты, позволяющие выявить эмоциональное состояние различных групп жительниц мегаполисов. Менее озвучены женские голоса провинции в год Первой мировой войны, несмотря на большое количество работ по истории отдельных регионов в этот период. Вне сомнения, различались женские переживания в годы войны в приграничных городах и глубоком тылу.

Это подтверждает предположение о том, что, единого, монолитного, эмоционального сообщества горожанок не могло быть несмотря на то, что жили в городах представительницы одинаковых сословий. Неоднородны и введенные в научный оборот источники: достаточно хорошо представлены эго-документы горожанок, которые входили в сообщество «фронтовичек» или взаимодействовали с фронтом; яркие и вполне репрезентативные документы демонстрируют позиции интеллектуалок (студенток, писательниц, журналисток) и практически не озвучены чувства и эмоции жительниц провинциальных городов.

По-своему переживали мировую войну крестьянки. Большую их часть составляли солдатки, и их позиция наиболее значима для оценки гендерной специфики восприятия войны. С одной стороны, на их плечи легла вся тяжесть «продовольственной программы» страны, они лишились привычного уклада жизни. С другой - вместе с финансовой помощью от государства за мужа, ушедшего на войну, солдатки получали финансовую и личную свободу.

Изменение социокультурной ситуации в годы мировой войны порождало новые коммуникативные практики. К сожалению, подобная эмансипация приводила иногда к девиациям в поведении крестьянок, что выражалось и в смене эмоциональных презентаций. Данные аспекты отражены в работах П. Щербинина, В.В. Крайкина ${ }^{69}$. Иллюстрацией к восприятию войны крестьянками может служить эпизод из воспоминаний баронессы фон Ренненкампф. Солдатки винили за отсутствие мужей не государство, не царя, а генерала: «Твой муж, генеральша, забрал наших мужей кормильцев на войну» ${ }^{70}$.

Следует признать, что для характеристики взглядов и настроений крестьянской части населения России, в особенности солдаток, необходимы источники личного происхождения. Однако записок и дневников жительницы деревень практически не оставили, а их письма на фронт введены в научный оборот ограничено, в отличие от писем с фронта ${ }^{71}$. Это вполне объяснимо: письма с фронта бережно хранились в домашних условиях, а сохранить письма в условиях военных действий или в госпитале было сложнее. Однако в фондах ГАРФа есть большая коллекция писем, которые не пропустила цензура. В них выражены истинные настроения солдаток. Кроме того, ярким подтверждением неприятия солдатками войны служат феномены бабьих бунтов. Это явление «продукта гендерного режима

${ }^{69}$ Крайкин В.В. Первая мировая война в восприятии крестьян (по материалам Орловской губернии). Брянск: Брян. гос. пед. ун-т им. И.Г. Петровского, 2009.

${ }^{70}$ Ренненкампф фон В. Из воспоминаний о Первой мировой войне // Звезда. 2013. № 8. URL: http://www.zh-zal.ru/zvezda/2013/8/9r.html (дата обращения: 15.10. 2018).

${ }^{71}$ Асташев А.Б. Русский фронт 1914-1917 гг.: военные письма // Исторический вестник. 2014. T. 9. № 156. C. 148-167. 
двойной нагрузки, возложенной на женщин» ${ }^{72}$ является ярким примером проявления коллективных эмоций.

Услышать голоса и эмоции работниц и крестьянок, с последнего года войны - свободных гражданок Советской России, позволяют документы, собранные в 1920-1930-е гг. историко-партийными комиссиями ${ }^{73}$. Истпарт был создан в Советской России в ответ на формировавшиеся в российском зарубежье коллекции мемуаров эмигрантов.

Последний год мировой войны для россиянок особенно знаменателен. С одной стороны, он явился самым кризисным по экономической, финансовой, продовольственной ситуации в стране, что порождало у женщин состояние недовольства, переходящего в открытые демонстрации негативных эмоций. С другой стороны, женщины в ходе начавшейся в стране политической перестройки получили долгожданные избирательные права. Апогей ликования по данному поводу - демонстрации женщин весной 1917 г., многократно описанные в прессе и мемуарах ${ }^{74}$. Женщины так самозабвенно радовались, наслаждаясь «сказочно прекрасной действительностью», что одна из них даже поздравила с праздником Свободы (такие проходили по всей стране) находившуюся под арестом в Царском селе императрицу: «Давно желанный час свободы наступил!» ${ }^{75}$. Однако следует согласиться с мнением профессора Гарвардского университета Рошель Ратчайлд, что «1917 самый изученный год в истории России XX века. Тем не менее ...в рассказах об этом революционном годе звучат... мужские голоса, ...вопрос о роли женщин в самых важных событиях России 1917 г. по-прежнему малоисследован» ${ }^{76}$. Отчасти решить задачу преодоления гендерного дисбаланса в ретроспекции 1917 года могли бы помочь исследования в русле истории эмоций. Например, в рамках данного направления возможно было бы сравнить эмоциональное проявление разноуровневых и даже полярных представителей разных эмоциональных сообществ, сопоставить их гендерные практики и мироощущения.

Политическая и семиотическая революции 1917 г. сопровождались разрушением традиционного общества. Революция принесла победу одним гражданам обновленной России, вызвав чувства энтузиазма, а другим - «бывшим» - крушение всех надежд. В источниках личного происхождения женщин «верхних» эмоциональных сообществ в это время усиливаются апокалиптические, эсхатологические мотивы, рефреном повторяются слова «катастрофа», «конец» и фразы: «все рухнуло», «все летит в там-тара-рам». Подобные ощущения были и у боль-

72 Перельман И.В. Влияние Первой мировой войны на развитие российского гендерного порядка. Феномен Марии Бочкаревой // Исторические, философские, политические и юридические науки, культурология и искусствоведение. Вопросы теории и практики. 2017. № 9 (83). С. 142-148.

${ }^{73}$ Морозова О.М., Трошина Т.И. Женский взгляд на мужскую работу. Революция и гражданская война глазами и в судьбах женщин // Новейшая история России. 2016. № 2. С. 8-30.

74 Закута О. Как в революционное время Всероссийская лига равноправия женщин добивалась избирательных прав для русских женщин. Пг.: Всерос. лига равноправия женщин, 1917. С. 23.

${ }^{75}$ ГАРФ. Ф. 640. Оп. 2. Д. 62. Л. 1.

${ }^{76}$ Ратчайлд Р. Непослушные женщины и русские революции 1917 года // Женщина в российском обществе. 2017. № 2 (83). С. 35-44, 36. 
шинства женщин городских сообществ, особенно у творческой интеллигенции. Зинаида Гиппиус пишет во второй «черной тетради»: «Душа моя полна до краев, и выше краев - льдом. ... Льдом, острым льдом полна моя душа» ${ }^{77}$.

Тем не менее, большинство отверженных россиян продолжают осмысление ситуации через нравственные категории: любовь (к родине), верность (долгу), предательство, измена. Например, сестра императора Ольга Александровна воспринимала вынужденную эмиграцию как предательство Родины. «У меня было такое чувство, что бегство - малодушие с моей стороны. ... меня постоянно мучил стыд», - вспоминала она ${ }^{78}$.

Несмотря на то, что революционной эпохой в истории российских женщин принято считать год 1917-й, на самом деле периодом революционного «перелицевания» наших соотечественниц стал 1918 год - последний год мировой войны. Социалистическая и семиотическая революции изменили облик страны, существенно повлияв на язык, письменность, систему летоисчисления, образный строй искусства, топонимику и т.п. ${ }^{79}$ Женщины страны Советов создали новые эмоциональные сообщества: работницы стали культурными героями, но скорее символами, нежели реалиями эпохи революции. К такому итогу привела женщин России Первая мировая война.

\section{Выводы}

Таким образом, гендеро-ориентированная история эмоций таит в себе неисчерпаемый исследовательский ресурс для новых научных изысканий, в том числе для осмысления сложных эпох российской истории. Одним из самых значимых для судьбы России является период Первой мировой войны. За 1914-1918 гг. в стране сменился политический режим, трансформировались социально-экономическая и культурная ситуации, изменился психологический климат. У историка есть уникальная возможность проследить весь спектр человеческих эмоций за годы войны, эволюцию и разнообразие общественных настроений от периода «медового месяца» патриотизма до революционного шквала «дней окаянных» (И. Бунин). Однако для проведения дискурсивного анализа в русле истории эмоций необходимо привлечение аутентичных исторических источников, прежде всего письменных.

Комплекс письменных источников, отражающий период 1914-1918 гг., достаточно велик и разнообразен. Это - архивные материалы, коллекции историкопартийных комиссий, опубликованные мемуары, письма, дневники, анкеты слушательниц высших женских курсов, публикации в женских журналах. Они демонстрируют изменение статуса, социальных ролей и самоидентичности женщин России в период Первой мировой войны, дают возможность провести психосемантический анализ стереотипов женского поведения в обстановке мировой катастрофы. Тем не менее, данный корпус свидетельств прошлого неравноценен по

77 Зинаида Гиппиус. Живые лица. Воспоминания. Тбилиси: Мередиан, 1991. С. 375.

${ }^{78}$ Ольга Александровна: мемуары. М.: Захаров, 2004. С. 181.

${ }^{79}$ Котылев А.Ю. «Мальчишка, люби Революцию...» Гендерный аспект развития российской культуры 1917-1933 гг. // Гендер и общество в истории. СПб.: Алетейа, 2007. С. 621. 
степени трансляции чувств и отражению эмоционального фона российской истории периода Первой мировой войны.

Кроме того, источники весьма неравномерно распределяются по женским «эмоциональным сообществам». Лучше всего озвучены чувства и эмоции представительниц «высшего света». Опубликованные источники личного происхождения (дневники, записки, письма, мемуары) и находящиеся в российских и зарубежных архивах документы позволяют провести измерение «сенсорных маркеров» элиты российского общества.

За период войны многие представительницы правящей династии поменяли ментальные установки, прошла корреляция их социальной и национальной идентичности. Некоторые из них впервые в жизни почувствовали себя социально востребованными, нашли свое призвание в общественном служении, что сказалось благотворно на их эмоциональном здоровье: они обрели «душевный покой» и даже «смысл жизни».

Письменные источники свидетельствуют, что в период военных потрясений меняются автостереотипы отдельных личностей, эволюционируют ценностные ориентации, расширяются пределы вариативности в отношениях с «чужими», «соседями» (гетеростереотипы), особенно с бывшими «классовыми врагами». Это касается тех эмоциональных сообществ, которые в «мирное время» отличались замкнутостью, были «зажаты» рамками конвенциональной корпоративной культуры с ее жесткой системой нормативных предписаний, межличностных и межгрупповых отношений.

Проведенное автором ранжирование эмоциональных сообществ выявило наиболее яркое по эмоциональным репрезентациям представительство - группу «фронтовичек». В данную корпорацию входили женщины не по социальной принадлежности, а по месту дислокации в период войны. Это были кураторы санитарных поездов, лазаретов, летучих отрядов, врачи и сестры милосердия. Дневники и записки сестер милосердия военного времени - наиболее ценные свидетельства эпохи. Это буквально «репортажи» из горячих точек, причем написанные гендерно-идентично: эмоционально, с непременной долей (но в разных соотношениях) лирики и публицистики.

Третьей категорией набора эмоциональных сообществ являлись городские жительницы. Их эмоции, настроения, переживания, смена внешних маркировок лучше всего транслировались в материалах женских журналов. Дамская пресса свидетельствует, что россиянки сумели сохранить свой мир (внутренний и внешний Mundus muliebris) и не допустить марганализации пола даже в годы мировой войны.

На последнем месте по «слышимости» голосов и репрезентативности источников оказались самые многочисленные слои населения - работницы и крестьянки, в том числе - особое эмоциональное сообщество - «солдатки». Их чаяния и восприятие эпохи отражены в так называемых «массовых источниках» - письмах, жалобах, прошениях. Однако, в силу плохой сохранности, именно женские письма, например, по сию пору не стали предметом специального рассмотрения историков. А между тем, гендерная специфика подобных письменных докумен- 
тов личного происхождения делает их неоценимым источником для воссоздания внутренних переживаний героев исторического процесса.

Ученые полагают, что невозможно понять исход мировых войн без анализа психологической атмосферы и менталитета различных слоев общества в военный период. Следовательно, новое направление научного поиска - история эмоций имеет вполне весомый потенциал для раскрытия более полной картины женского мира. В письменных источниках периода мировой войны женские чувства и эмоции представлены широкой палитрой. Необходимо использовать весь комплекс данных свидетельств эпохи для реконструкиции сложного эмоционального гендерно-маркированного ландшафта прошлого.

(C) Чуракова О.В., 2019

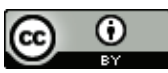

This work is licensed under a Creative Commons Attribution 4.0 International License

Рукопись поступила: 14 февраля 2019 г.

Submitted: 14 Febraury 2019

\section{Библиографический список}

Акишина С.Н., Беланова А.М., Зверкова Н.С., Беляков Н.А. Сестры милосердия в России. Начало ХІХ - начало XX века. М.: Альянс. 2014.

Асташев А.Б. Русский фронт 1914-1917 гг.: военные письма // Исторический вестник. 2014. Т. 9. № 156. С. 148-167.

Бакиутов В.К. Философия чувств: информационная концепция. Екатеринбург: УрО РАН, 1996.

Белова T.B. Социальное положение женщин-работниц в губерниях Верхнего Поволжья в годы первой мировой войны // Женщины и российское общество: научно-исторический аспект. Иваново: изд-во Ивановского Государственного Университета, 1995. С. 77-81.

Большакова O. В. Проблемы и перспективы гендерной истории Первой мировой войны. URL: http:// legacy.inion.ru/index.php?page_id=534

Варнек Т.A. Воспоминания сестры милосердия (1912-1922). URL: www.dk1868.ru/history/varnek/ varnek1.htm

Винниикий И. Заговор чувств, или Русская история на «эмоциональном повороте» (Обзор работ по истории эмоций) // Новое литературное обозрение. 2012. № 117. С. 441-460.

Ветлесен А.Ю. Философия боли. М.: Прогресс-Традиция, 2010.

Веселовский А.Н. Избранные статьи. Л.: Гослитиздат, 1939.

Воррес Я. Ольга Александровна: мемуары. М.: Захаров, 2004.

Гафурова Х.Ш. Некоторые критерии жанровой идентификации средневековых японских дневников // Молодой ученый. 2011. № 6. Т. 2. С. 15-17.

Глафирова В.В., Селунская Е.А., Манилов Р.А. Записки сестры милосердия Анны Ждановой. Тверь: ООО Издательство «Триада», 2014.

Голубцов В.С. Мемуары как источник по истории советского общества. М.: Издательство Московского университета, 1970.

Гиппиус 3.Н. Дневники. URL: http://az.lib.ru/g/gippius_z_n/text_0070.shtml (дата обращения: 11.01.2019). Гиппиус 3.Н. Живые лица. Воспоминания. Тбилиси: Мередиан, 1991.

Дементьев И.О. Современная историография о гендерных аспектах истории Первой мировой войны // Вестник Балтийского федерального университета им. И. Канта. Серия: Гуманитарные и общественные науки. 2014. № 12. С. 84-93. 
Денисенко С.В. Все страхи мира: Horror в литературе и искусстве. Сб. статей. СПб.-Тверь: Изд-во Марины Батасовой, 2015.

Закута О. Как в революционное время Всероссийская лига равноправия женщин добивалась избирательных прав для русских женщин. Пг.: Всерос. лига равноправия женщин, 1917.

Зорин А. История эмоций. URL: http://polit.ru/article/2004/06/18/zorin.

Зорин A. Появление героя: из истории русской эмоциональной культуры конца XVIII - начала XIX века. М.: Новое литературное обозрение. 2016.

Иванова Ю.Н. Храбрейшие из прекрасных: Женщины России в войнах. М.: РОССПЭН, 2002.

Иванова Е.В. О реконструкции комплекса архивных материалов о благотворительной деятельности великой княгини Елизаветы Федоровна // Вестник архивиста. 2013. № 3. С. 101-112.

Игельстром А. Воспоминания о Первой Мировой войне Ольги Григорьевны Федюкиной-Имберх // Проза. Py. URL: https://www.proza.ru/2017/08/26/1230 (дата обращения: 12.01. 2019).

Кауфман А.А. Слушательницы Петроградских высших женских (Бестужевских) курсов на втором году войны. Бюджет. Жилищные условия. Питание. По данным переписи (анкеты), выполн. Стат. Семинарием в конце окт. 1915 г. Петроград: [Б.и.], 1916.

Караяни А.Г. Психология войны: постановка проблемы с позиций военно-психологической науки // Военно-историческая антропология. Ежегодник. М.: РОССПЭН, 2002. С. 39-41.

Козьменко В.М., Керов В.В. Межвузовский научный центр сопоставительных историко-антропологических исследований «Историко-антропологическая компаративистика» // Вестник Российского университета дружбы народов. Серия: История России. 2002. № 1. С. 118-119.

Колоницкий Б.И. Революция 1917 года. М.: Эксмо, 2018.

Колониикий Б.И. Образ сестры милосердия в российской культуре эпохи Первой мировой войны // Большая война России: социальный порядок, публичная коммуникация и насилие на рубеже царской и советской эпох: сборник статей. М.: Новое литературное обозрение, 2014. С. $100-126$.

Котылев А.Ю. «Мальчишка, люби Революцию...» Гендерный аспект развития российской культуры 1917-1933гг. // Гендер и общество в истории. СПб.: Алетейа, 2007. С. 621-657.

Кудрин Ю.В. Дневники императрицы Марии Фёдоровны (1914-1920, 1923 годы). М.: Вагриус, 2005.

Крайкин В. В. Первая мировая война в восприятии крестьян (по материалам Орловской губернии). Брянск: Брян. гос. пед. ун-т им. И.Г. Петровского, 2009.

Лившин А. Настроения и политические эмоции в Советской России 1917-1932 гг. М.: РОССПЭН, 2010.

Максимова Ю.О. Письма Александры Федоровны к Николаю II Александровичу как источник для осмысления мотивации благотворительной деятельности императрицы в 1914 г. // Ars Historica. Проблемы интерпретации исторических источников. 2017. С. 115-120.

Морозов С.Д. Мужчины и женщины в России в годы Первой мировой войны: демографический кризис и потери населения // Женщина в российском обществе. 2014. № 3 (72). С. 10-20.

Морозова О.М., Трошина Т.И. Женский взгляд на мужскую работу. Революция и гражданская война глазами и в судьбах женщин // Новейшая история России. 2016. № 2. С. 8-30.

Мицюк Н.А., Пушикарёва Н.Л. «Не только перевязка мужских ран»: историко - антропологическое исследование медицинского сестринства в годы Первой мировой войны // Сибирские исторические исследования. 2018. № 2. С. 244-252.

Нагорная О.С. «Полковник беззвучно зарыдал, слезы были на глазах у всех офицеров...» Коммуникация эмоций за колючей проволокой // Диалог со временем. 2011. № 35. С. 195-205.

Некрасова Е. Из прошлого женских курсов. М.: издание типографии А.А. Карцева, 1886.

Палмер Я. Российская империя чувств: Подходы к культурной истории эмоций. М.: Новое обозрение, 2010. 
Поршнев Б.Ф., Анцыферов Л.И. История и психология. Сборник. Москва: Наука, 1971.

Поршнев Б. Социальная психология и история. Рига: Звайгэне, 1982.

Поршнева О.С. Человек в условиях российской революции 1917 года: основные тенденции и достижения в изучении проблемы // 1917 года в России: социалистическая идея, революционная мифология и практика. Екатеринбург: изд-во Урал. ун-та, 2016. С. 50-64.

Поринева О.С. Крестьяне, рабочие и солдаты России накануне и в годы Первой мировой войны. М.: РОССПЭН, 2004.

Первушина Е. Быть сестрой милосердия. Женский лик войны. М.: Алгоритм, 2017.

Перельман И.В. Влияние Первой мировой войны на развитие российского гендерного порядка. Феномен Марии Бочкаревой // Исторические, философские, политические и юридические науки, культурология и искусствоведение. Вопросы теории и практики. 2017. № 9 (83). С. 142-148.

Пушккарёва Н.Л. Публичное вторжение в частную жизнь (эвристическая ценность устных и письменных эго-документов для гендерной истории) // Запад - Восток. 2018. № 11. С. 161-179.

Пушккарёва Н.Л. У истоков женской автобиографии в России // Филологические науки. 2000. № 3. C. $62-70$.

Пушкарёва Н.Л. Мемуары и автобиографии женщин как исследовательский «полигон» для изучения «женского письма» // Е.Р. Дашкова и XVIII век. Традиции и новые подходы. М.: МГИ им. Е.Р. Дашковой, 2012. С. 224-241.

Pay И. О чувствах и эмоциях как предмете истории, философии и культурологии: очерк комплексной проблемы // Современная научная мысль. 2015. № 4. С. 109-118.

Pannanopm X. Дневники княжон Романовых. Загубленные жизни. Пер. с англ. И. Мовчан. М.: ООО «Издательство «Э», 2015.

Pannonopm X. Застигнутые революцией. Живые голоса очевидцев. Пер. с англ. И. Мовчан. М.: ООО «Издательство «Э», 2017.

Ратчайлд Р. Непослушные женщины и русские революции 1917 года // Женщина в Российском обществе. 2017. № 2 (83). С. 35-44.

Репина Л.П. История исторического знания. Пособие для вузов. М.: Дрофа: Высшее образование, 2004.

Ренненкампф фон, В. Из воспоминаний о Первой мировой войне // Звезда. 2013. № 8. С. 125-141.

Сваре X. Философия дружбы. М.: Прогресс-Традиция, 2010.

Свендсен Л. Философия страха. М.: Прогресс-Традиция, 2010.

Сенявская Е.С. Психология войны в ХХ веке. М.: РОССПЭН. 1999.

Семина Х.Д. Записки сестры милосердия: Кавказский фронт. 1914-1918 гг. М.: Кучково поле, Горные технологии. 2016.

Симонова О. Изучение эмоций как область междисциплинарной интеграции: история и социология в поисках объяснения «эмоционального поворота». К выходу русского перевода криги Яна Плампера «История эмоций» // Социологическое обозрение. 2018. Т. 17. №. 3. С. 356-378.

Симонова О.А. Базовые принципы социологии эмоций // Вестник СПбГУ. Сер. 12. Социология. 2016. № 4. С. 12-27.

Симонова О. Изучение эмоций как область междисциплинарной интеграции: история и социология в поисках объяснения «эмоционального поворота». К выходу русского перевода книги Яна Плампера «История эмоций» // Социологическое обозрение. 2018. Т. 17. №. 3. С. 356-378.

Синова И.В. «В свободной России не должно быть прежней женщины-рабы», или о чем писали отечественные журналы в 1917 г. // Женщина в российском обществе. 2014. № 3 (72). С. 98-106.

Фармборо Ф. Первая мировая война. Дневники с фронта. М.: ОЛМА Меда Групп, 2014.

Филимонова О.Е. Эмоциология текста. Анализ репрезентации эмоций в английском тексте: Учебное пособие. СПб.: ООО «Книжный Дом», 2007. 
Щербинин П.П. Военный фактор в повседневной жизни русской женщины в XVIII - начале XX века. Тамбов: Изд-во Юлис, 2004.

Coryne Hall. Little mother of Russia : a biography of the Empress Marie Feodorovna (1847-1928). London: Shepheard-Walwyn, [1999] 2006.

Simonova O. Capitalist Heart: Rationality, Emotion and Alienation in Late Modern Societies // Power, Violence and Justice: reflections, responses and responsibilities. Book of Abstracts accepted for presentation at the XIX ISA World Congress of Sociology Toronto, Canada, July 15-21, 2018. Toronto: International Sociological Association. P. 891.

L.S. Stoff, They Fought for the Motherland: Russia's Women Soldiers in World War I and the Revolution (Kansas: University Press of Kansas, 2006); L.S. Stoff, Russia's Sisters of Mercy and the Great War : more than binding men's wounds (Kansas: University press of Kansas, 2015).

\section{References}

Akishina, S.N., Belanova, A.M., Zverkova, N.S., and Belyakov, N.A. Sestry miloserdiya v Rossii. Nachalo XIX - nachalo XX veka. Moscow: Al'yans Publ., 2014 (in Russian).

Astashev, A.B. "Russkiy front 1914-1917 gg.: voyennyye pis'ma.” Istoricheskiy vestnik, no. 156 (2014): 148-167 (in Russian).

Bakshutov, V.K. Filosofiya chuvstv: informatsionnaya kontseptsiya. Yekaterinburg: UrO RAN Publ., 1996 (in Russian).

Belova, T.V. "Sotsial'noe polozhenie zhenshchin-rabotnits v guberniyakh Verkhnego Povolzh'ya v gody pervoi mirovoi voiny." In Zhenshchiny i rossiiskoe obshchestvo: nauchno-istoricheskii aspekt. Ivanovo: Ivanovo State University Publ., 1995 (in Russian).

Bol'shakova, O.V. Problemy i perspektivy gendernoi istorii Pervoi mirovoi voiny. http://inion.ru/index. php?page_id=534 (in Russian).

Coryne, Hall. Little mother of Russia. A biography of the Empress Marie Feodorovna (1847-1928). London: Shepheard-Walwyn Publ., 1999.

Dement'ev, I.O. "Sovremennaya istoriografiya gendernykh aspektov istorii Pervoi mirovoi voiny." Vestnik Baltiiskogo federal'nogo universiteta im. I. Kanta, no. 12 (2014): 84-93 (in Russian).

Denisenko, S.V. Vse strakhi mira: Horror v literature i iskusstve. Sb. statei. SPb. Tver: izd-vo Mariny Batasovoi Publ., 2015 (in Russian).

Farmboro, F. Pervaya mirovaya voyna. Dnevniki s fronta. Moscow: OLMA Meda Grupp Publ., 2014 (in Russian).

Filimonova, O.E. Emotsiologiya teksta. Analiz reprezentatsii emotsii v angliiskom tekste: Uchebnoe posobie. St. Petersburg: OOO Knizhnyi Dom Publ., 2007 (in Russian).

Gafurova, Kh.Sh. "Nekotorye kriterii zhanrovoi identifikatsii srednevekovykh yaponskikh dnevnikov." Molodoi uchenyi, no. 6 (2011): 15-17. https://moluch.ru/archive/29/3282/ (Accessed: 17.01.2019) (in Russian).

Gippius, Z.N. Zhivye litsa. Vospominaniya. Tbilisi: Meredian Publ., 1991 (in Russian).

Gippius, Z.N. Dnevniki. Moscow: Zakharov Publ., 2017 (in Russian).

Glafirova, V.V., Selunskaya E.A., and Manilov, R.A. Zhdanova, A. A. Zapiski sestry miloserdiya Anny Zhdanovoi. Tver: Triada Publ., 2014 (in Russian).

Golubtsov, V.S. Memuary kak istochnik po istorii sovetskogo obshchestva. Moscow: Moskovskogo universiteta Publ., 1970 (in Russian).

Igel'strom, A. Vospominaniya o Pervoi Mirovoi voine Ol'gi Grigor'evny Fedyukinoi-Imberkh. https:// www.proza.ru/2017/08/26/1230 (in Russian).

Ivanova, E.V. "About restoration of archive material complex of Grand Duchess Elizabeth Feodorovna philanthropic activity." Vestnik arkhivista / Herald of an Archivist, no. 3 (2013): 101-112 (in Russian).

Ivanova, Y.N. Hrabreyshie iz prekrasnyh. Zhenshhiny Rossii v vojnah. Moscow: ROSSPEN Publ., 2002 (in Russian). 
Karayani, A.G. "Psikhologiya voiny: postanovka problemy s pozitsii voenno-psikhologicheskoi nauki." In Voenno-istoricheskaya antropologiya. Ezhegodnik. Moscow: Rosspen Publ., 2002 (in Russian).

Kaufman, A.A. Slushatel'nitsy Petrogradskikh vysshikh zhenskikh (Bestuzhevskikh) kursov na vtorom godu voiny. Byudzhet. Zhilishchnye usloviya. Pitanie. Po dannym perepisi (ankety), vypoln. Stat. Seminariem v kontse okt. 1915 g. Petrograd: [S.n.], 1916 (in Russian).

Kolonitskii, B.I. Revolyutsiya 1917 goda Moscow: Eksmo Publ., 2018 (in Russian).

Kolonitskiy, B.I. "Obraz sestry miloserdiya v rossiyskoy kul'ture epokhi Pervoy mirovoy voyny." In Bol'shaya voyna Rossii: sotsial'nyy poryadok, publichnaya kommunikatsiya i nasiliye na rubezhe tsarskoy i sovetskoy epokh: sbornik statey. Moscow: Novoye literaturnoye obozreniye Publ., 2014 (in Russian).

Kotylev, A.Y. “ 'Mal'chishka, lyubi Revolyutsiyu...' Gendernyi aspekt razvitiya rossiiskoi kul'tury 19171933 gg." In Gender i obshchestvo v istorii, 621-657. St. Petersburg: Aleteya Publ., 2007 (in Russian).

Koz'menko, V.M. and Kerov V.V. "Mezhvuzovskii nauchnyi tsentr sopostavitel'nykh istoriko-antropologicheskikh issledovanii 'Istoriko-antropologicheskaya komparativistika'.” RUDN Journal of Russian History 1, no. 1 (2002): 118-119 (in Russian).

Kraikin, V.V. Pervaya mirovaya voina v vospriyatii krest'yan (po materialam orlovskoi gubernii). Bryansk: Bryansk State Pedagogical University Publ., 2009 (in Russian).

Kudrina, Y.V. Mariya Fedorovna, imperatritsa. Dnevniki imperatritsy Marii Fedorovny (1914-1920, 1923 gody). Moscow: Wagrius Publ., 2005 (in Russian).

Kudrina, Y.V. Dnevniki imperatritsy Marii Fedorovny (1914-1920, 1923 gody). Moscow: Vagrius Publ., 2005 (in Russian).

Livshin, A. Nastroeniya i politicheskie emotsii v Sovetskoi Rossii 1917-1932 gg. Moscow: ROSSPEN Publ., 2010 (in Russian).

Maksimova, Y.O. "Pis'ma Aleksandry Fedorovny k Nikolayu II Aleksandrovichu kak istochnik dlya osmysleniya motivatsii blagotvoritel'noi deyatel'nosti imperatritsy v 1914 g." Ars Historica Problemy interpretatsii istoricheskikh istochnikov (2017): 115-120 (in Russian).

Mitsyuk, N.A., and Pushkareva, N.L. “ 'Ne tol'ko perevyazka muzhskikh ran': istoriko-antropologicheskoe issledovanie meditsinskogo sestrinstva v gody Pervoi mirovoi voiny." Sibirskie istoricheskie issledovaniya, no. 2 (2018): 244-252 (in Russian).

Morozov, S.D. "Muzhchiny i zhenshchiny v Rossii v gody Pervoi mirovoi voiny: demograficheskii krizis i poteri naseleniya." Zhenshchina v rossiiskom obshchestve, no. 3 (2014): 10-20 (in Russian).

Morozova, O.M., and Troshina, T.I. "Woman's View at Men's Work: The Revolution and the Civil War through the Eyes of Women and Through Their Fates." Modern History of Russia, no. 2 (2016): 8-30 (in Russian).

Nagornaya, O.S. "Polkovnik bezzvuchno zarydal, slezy byli na glazakh u vsekh ofitserov..." Kommunikatsiya emotsii za kolyuchei provolokoi.” Dialog, no. 35 (2011) (in Russian).

Nekrasova, E. Iz proshlogo zhenskikh kursov. Moscow: izdanie tipografii A.A. Kartseva Publ., 1886 (in Russian).

Palmper, Y., Shakhadat Sh., and Eli, M. Rossiiskaya imperiya chuvstv: Podkhody k kul'turnoi istorii emotsii. Moscow: Novoe obozrenie Publ., 2010 (in Russian).

Perel'man, I.V. "Vliyanie Pervoi mirovoi voiny na razvitie rossiiskogo gendernogo poryadka. Fenomen Marii Bochkarevoi." Istoricheskie, filosofskie, politicheskie i yuridicheskie nauki, kul'turologiya $i$ iskusstvovedenie. Voprosy teorii i praktiki, no. 9 (2017): 142-148 (in Russian).

Pervushina, Ye. Byt'sestroy miloserdiya. Zhenskiy lik voyny. Moscow: Algoritm Publ., 2017 (in Russian).

Porshnev, B.F., and Antsyferova, L.I. Istoriya i psikhologiya. Sbornik. Moscow: Nauka Publ., 1971 (in Russian).

Porshnev, B. Sotsial'naya psikhologiya i istoriya. Riga: Zvaigene Publ., 1982 (in Russian). 
Porshneva, O.S. "Chelovek v usloviyakh rossiiskoi revolyutsii 1917 goda: osnovnye tendentsii i dostizheniya v izuchenii problem.” In 1917 goda v Rossii: sotsialisticheskaya ideya, revolyutsionnaya mifologiya i praktika: sb. nauch. trudov. Yekaterinburg: Ural University Publ., 2016 (in Russian).

Porshneva, O.S. Krest'yane, rabochie i soldaty Rossii nakanune i v gody Pervoi mirovoi voiny. Moscow: ROSSPEN Publ., 2004 (in Russian).

Pushkareva, N.L. 'Publichnoye vtorzheniye v chastnuyu zhizn' (evristicheskaya tsennost' ustnykh i pis'mennykh ego-dokumentov dlya gendernoy istorii)." Zapad - Vostok, no. 11 (2018): 161-179 (in Russian).

Pushkareva, N.L. "U istokov zhenskoy avtobiografii v Rossii.” Filologicheskiye nauki, no. 3 (2000): 62-70 (in Russian).

Pushkareva, N.L. "Memuary i avtobiografii zhenshchin kak issledovatel'skiy «poligon» dlya izucheniya 'zhenskogo pis'ma'.” In Ye.R. Dashkova i XVIII vek. Traditsii i novyye podkhody. Moscow: MGI im. Ye. R. Dashkovoy Pub., 2012 (in Russian).

Rappaport, Kh. Dnevniki knyazhon Romanovykh. Zagublennye zhizni. Per. s angl. I. Movchan. Moscow: E Publ., 2015 (in Russian).

Rappoport, Kh. Zastignutye revolyutsiei. Zhivye golosa ochevidtsev. Per. s angl. I. Movchan. Moscow: E Publ., 2017 (in Russian).

Ratchaild, R. "Neposlushnye zhenshchiny i russkie revolyutsii 1917 goda." Zhenshchina v Rossiiskom obshchestve, no. 2 (2017): 35-44 (in Rusian).

Rau, I. "O chuvstvakh i emotsiyakh kak predmete istorii, filosofii i kul'turologi: ocherk kompleksnoi problem.” Sovremennaya nauchnaya mysl':Zhurnal NII istorii, ekonomiki i prava, no 4 (2015): 109118, 110 (in Russian).

Rennenkampf fon, V." Iz vospominanii o Pervoi mirovoi voine." Zvezda, no. 8 (2013): 125-141 (in Russian).

Repina, L.P. Istoriya istoricheskogo znaniya. Posobie dlya vuzov. Moscow: Drofa Publ., 2004 (in Russian).

Semina, Kh.D. Zapiski sestry miloserdiya: Kavkazskii front. 1914-1918 gg. Moscow: Kuchkovo pole Publ., 2016 (in Russian).

Senyavskaya, E.S. Psikhologiya voiny v XX veke: istoricheskii opyt Rossii. Moscow: ROSSPEN Publ., 1999 (in Russian).

Shcherbinin, P.P. Voennyi faktor v povsednevnoi zhizni russkoi zhenshchiny $v$ XVIII - nachale XX veka. Tambov: Yulis Publ., 2004 (in Russian).

Simonova, O. "Capitalist Heart: Rationality, Emotion and Alienation in Late Modern Societies." Power, Violence and Justice: reflections, responses and responsibilities. Book of Abstracts accepted for presentation at the XIX ISA World Congress of Sociology Toronto, Canada, July 15-21, $2018,891$. Toronto: International Sociological Association Publ., 2018.

Simonova, O. "Izuchenie emotsii kak oblast' mezhdistsiplinarnoi integratsii: istoriya i sotsiologiya v poiskakh ob"yasneniya 'emotsional'nogo povorota'. K vykhodu russkogo perevoda krigi Yana Plampera 'Istoriya emotsii'." Sotsiologicheskoe obozrenie, no. 3 (2018): 356-378 (in Russian).

Simonova, O.A. "Basic principles the sociology of emotions." Vestnik SPbSU. Series 12. Sociology, no. 4 (2016): 12-27 (in Russian).

Sinova, I.V. “ 'V svobodnoi Rossii ne dolzhno byt' prezhnei zhenshchiny-raby', ili o chem pisali otechestvennye zhurnaly v 1917 g." Zhenshchina v rossiiskom obshchestve, no. 3 (2014): 98-106 (in Russian).

Stoff, Laurie S. They fought for the motherland: Russia's women soldiers in World War I and the revolution. Kansas: University Press of Kansas, 2006.

Svare, Kh. Filosofiya druzhby per. s norvezhskogo I. Voronovoy. Moscow: Progress-Traditsiya Publ., 2010 (in Russian).

Svendsen, L. Filosofiya strakha. Moscow: Progress-Traditsiya Publ., 2010 (in Russian).

Varnek, T.A. Vospominaniya sestry miloserdiya (1912-1922). http://www.dk1868.ru/history/varnek/varnek1.htm. (Accessed: 11.01.2019) (in Russian). 
Veselovskii, A.N. Izbrannye stat'i. St. Petersburg: Goslitizdat Publ., 1939 (in Russian).

Vetlesen, A.Yu. Filosofiya boli. Moscow: Progress-Traditsiya Publ., 2010 (in Russian).

Vinnitskiy, I. "Zagovor chuvstv ili russkaya istoriya na emotsional'nom povorote. (Obzor rabot po istorii emotsii)." Novoe literaturnoe obozrenie, no. 117 (2012): 441-460 (in Russian).

Vorres, I. Ol'ga Aleksandrovna. Memuary. Zapis'Ya. Vorresa. Moscow: Zakharov Publ., 2003 (in Russian).

Zakuta, O. Kak v revolyutsionnoe vremya Vserossiiskaya liga ravnopraviya zhenshchin dobivalas' izbiratel'nykh prav dlya russkikh zhenshchin. Petrograd: Vseros. liga ravnopraviya zhenshchin Publ., 1917 (in Russian).

Zorin, A. Istoriya emotsii. http://polit.ru/article/2004/06/18/zorin (in Russian).

Zorin, A. Poyavleniye geroya: iz istorii russkoy emotsional'noy kul tury kontsa XVIII - nachala XIX veka. Moscow: Novoye literaturnoye obozreniye Publ., 2016 (in Russian).

\section{Информация об авторе / Information about the author}

Чуракова Ольга Владимировна, кандидат Olga V. Churakova, Candidate of Historical исторических наук, доцент кафедры отечественной истории Высшей школы социальногуманитарных наук и международной коммуникации Северного Арктического Федерального Университета имени М.В. Ломоносова. Sciences, Associate Professor of the Department of Domestic History of the Higher School of Social Sciences, Humanities and International Communication, Northern (Arctic) Federal University named after M.V. Lomonosov. 